\title{
Advances in Oxidative Desulfurization of Fuel Oils over MOFs-Based Heterogeneous Catalysts
}

\author{
Hongsi Luo $(\mathbb{D}$, Yulong Gu, Daqing Liu and Yinyong Sun *(1) \\ MIIT Key Laboratory of Critical Materials Technology for New Energy Conversion and Storage, \\ School of Chemistry and Chemical Engineering, Harbin Institute of Technology, Harbin 150001, China; \\ hsluo1795938568@163.com (H.L.); ylg10141721@163.com (Y.G.); LDQ205786375@163.com (D.L.) \\ * Correspondence: yysun@hit.edu.cn
}

Citation: Luo, H.; Gu, Y.; Liu, D.; Sun, Y. Advances in Oxidative Desulfurization of Fuel Oils over MOFs-Based Heterogeneous Catalysts. Catalysts 2021, 11, 1557. https://doi.org/10.3390/ catal11121557

Academic Editor: Haralampos N. Miras

Received: 11 November 2021 Accepted: 30 November 2021 Published: 20 December 2021

Publisher's Note: MDPI stays neutral with regard to jurisdictional claims in published maps and institutional affiliations.

Copyright: (c) 2021 by the authors. Licensee MDPI, Basel, Switzerland. This article is an open access article distributed under the terms and conditions of the Creative Commons Attribution (CC BY) license (https:// creativecommons.org/licenses/by/ $4.0 /)$.

\begin{abstract}
Catalytic oxidative desulfurization (ODS) of fuel oils is considered one of the most promising non-hydrodesulfurization technologies due to the advantages of mild reaction conditions, low cost and easy removal of aromatic sulfur compounds. Based on this reason, the preparation of highly efficient ODS catalysts has been a hot research topic in this field. Recently, metal-organic frameworks (MOFs) have attracted extensive attention due to the advantages involving abundant metal centers, high surface area, rich porosity and varied pore structures. For this, the synthesis and catalytic performance of the ODS catalysts based on MOFs materials have been widely studied. Until now, many research achievements have been obtained along this direction. In this article, we will review the advances in oxidative desulfurization of fuel oils over MOFs-based heterogeneous catalysts. The catalytic ODS performance over various types of catalysts is compared and discussed. The perspectives for future work are proposed in this field.
\end{abstract}

Keywords: oxidative desulfurization; MOFs; porous material; fuel oils; dibenzothiophene

\section{Introduction}

Fuel oils are widely used in human life and are the main energy consumption products in the world [1]. With the continuous growth of the world population and the gradual development of industrial levels, the energy crisis and environmental protection have attracted more and more attention $[2,3]$. It is well known that there are some sulfur-containing molecules in fuel oils. The combustion of such molecules releases $\mathrm{SO}_{\mathrm{x}}$ compounds, which not only greatly hinders the processing and production but also brings about serious environmental problems [4]. The composition of sulfur-containing molecules is complex and includes thiols, sulfides, disulfides and thiophene compounds [5]. In particular, thiophene compounds such as thiophene (T), benzothiophene (BT), dibenzothiophene (DBT) and their alkyl derivatives account for a relatively high proportion of the sulfides in fuel oils. The removal of these compounds is of great significance to protect the environment and produce clean fuel oils.

Nowadays, countries around the world have imposed strict restrictions on the sulfur content in fuel oils. Many have demanded that the sulfur level be below $10 \mathrm{ppm}$. This means that the sulfur-containing molecules like 4,6-dimethyldibenzothiophene (4,6DMDBT) must be desulfurized. However, it is very difficult to realize this process by industrial hydrodesulfurization (HDS) technology. This drives researchers to develop new desulfurization techniques. Indeed, several non-hydrodesulfurization technologies including adsorption desulfurization (ADS) [6], extraction desulfurization (EDS) [7], biological desulfurization (BDS) [8] and oxidative desulfurization (ODS) have been widely investigated. Therefore, ODS technology is considered one of the most promising nonhydrodesulfurization technologies due to advantages such as mild reaction conditions, low cost and easy removal of aromatic sulfur compounds. Thus, the development of highly efficient ODS heterogeneous catalysts has been pursued. 
Currently, various types of heterogeneous catalysts involving metal oxides [9], boron nitride [10], reduced graphene oxide (rGO) [11], Ti-containing porous materials $[12,13]$ and metal-organic frameworks (MOFs) [14,15] have been attempted for ODS reactions of fuel oils. Among them, MOFs have received much attention due to advantages such as abundant metal centers, high surface areas and varied pore structures, which are composed of secondary building units (SBUs) connected by organic linkers to form crystalline porous materials. Such materials possess both the rigidity of inorganic materials and the flexibility of organic materials. Moreover, rich metal centers in the structure of MOFs could be catalytic active sites for some chemical reactions [16]. For this, the synthesis and catalytic performance of the ODS catalysts based on MOFs materials have been widely studied [17-19]. Among this research work, MOFs have been used mainly as ODS catalysts or composite catalysts with additional active species or sacrificial templates producing ODS active centers. The ODS performance of catalysts has mostly been evaluated by the catalytic oxidation reactions of BT, DBT and 4,6-DMDBT. In the reaction system, the used oxidants involve $\mathrm{H}_{2} \mathrm{O}_{2}$, tert-butyl hydroperoxide (TBHP), cumene hydroperoxide (CHP), $\mathrm{O}_{2}$ and air. The reaction temperature is generally below $80^{\circ} \mathrm{C}$, although the oxidation temperature is used up to $150^{\circ} \mathrm{C}$ in the case of $\mathrm{O}_{2}$ or air as an oxidant.

In this review, we will summarize the advances in oxidative desulfurization of fuel oils over MOFs-based heterogeneous catalysts. The catalytic ODS performance over various types of catalysts is compared and discussed. The opportunities and challenges for future work are proposed in this field.

\section{MOFs as ODS Catalysts}

\subsection{Ti-MOFs as ODS Catalysts}

In the earlier studies, the Ti species in titanium-containing zeolites and mesoporous silica have been demonstrated to be active in the ODS reactions of sulfur-containing compounds [20,21]. However, the content of the introduced Ti species into the framework is low $(<5 \mathrm{wt} . \%)$ due to the limitation of the structure. Compared with these Ti-containing porous materials, Ti-MOFs are promising candidates for ODS reactions due to the presence of rich Ti sites in their structure. As a member of Ti-MOFs, MIL-125(Ti) is attractive. In its structure, the basic unit of MIL-125(Ti) is $\mathrm{Ti}_{8} \mathrm{O}_{8}(\mathrm{OH})_{4}-\left(\mathrm{O}_{2} \mathrm{C}-\mathrm{C}_{6} \mathrm{H}_{5}-\mathrm{CO}_{2}\right)_{6}$ and a cyclic octamer is composed of titanium octahedral units shared by corners or edges. These cyclic octamers are connected to the other 12 cyclic octamers through BDC linkers to form a porous three-dimensional periodic array with two types of cages. One type of cage is an octahedron $(12.5 \AA)$ and the other is a tetrahedron $(6 \AA)$ [22].

In 2013, Se-Na Kim and coworkers first reported that MIL-125(Ti) was active in the oxidative desulfurization of DBT [23]. In this work, the catalytic ODS performance of MIL-125(Ti) was evaluated and compared with traditional microporous and mesoporous titanium silicates. The results showed that the order of DBT conversion under the same reaction conditions was Meso-TS-1 > MIL-125(Ti) > Micro-TS-1 (Table 1), which is in accordance with the window size in porous materials. This result suggests that pore size also plays an important role in the ODS reactions of sulfur compounds besides $\mathrm{Ti}$ species. To overcome the limitation of micropore size, meso-MIL-125(Ti) with mesopores was synthesized in the presence of surfactant by vapor-assisted crystallization method [24]. The catalytic results further demonstrate that the introduction of mesopores could improve the catalytic ODS performance of MIL-125(Ti). Additionally, Li et al. investigated the catalytic performance of MIL-125(Ti) and $\mathrm{NH}_{2}$-MIL-125(Ti) with different crystal sizes; MIL-125(Ti)-L with large crystal size showed the best catalytic performance when $\mathrm{H}_{2} \mathrm{O}_{2}$ was used as oxidant [25]. It is thought that MIL-125(Ti) with large crystal size hould possess more coordination-unsaturated Ti(IV) sites, which is more favorable for catalytic oxidative desulfurization. Although some progress on MIL-125(Ti) has been made, its structural stability is still an issue during the ODS reactions. 
Table 1. Comparison of catalytic performance over various Ti-MOFs in the ODS reactions of model fuel oil.

\begin{tabular}{|c|c|c|c|c|c|c|c|c|}
\hline Catalyst & $\begin{array}{l}\text { Substrate } \\
\text { (S Content) }\end{array}$ & Oxidant & $\begin{array}{c}\text { O/S } \\
\text { Ratio }\end{array}$ & $\begin{array}{l}\text { Temp. } \\
\left({ }^{\circ} \mathrm{C}\right)\end{array}$ & $\begin{array}{l}\text { Time } \\
(\mathrm{min})\end{array}$ & $\begin{array}{c}\text { Sulfur } \\
\text { Removal } \\
(\%)\end{array}$ & $\begin{array}{c}\text { Activity } \\
\left(\mathrm{mmol}^{\prime} \mathrm{g}^{-1} \cdot \mathrm{h}^{-1}\right)\end{array}$ & Ref. \\
\hline \multirow[t]{3}{*}{ MIL-125(Ti) } & DBT (200 ppm) & $\mathrm{CHP}$ & 15 & 80 & 180 & 36 & 0.30 & \multirow{3}{*}[23]{} \\
\hline & 4-MDBT (200 ppm) & & & & & 15 & 0.12 & \\
\hline & 4,6-DMDBT (200 ppm) & & & & & 12 & 0.10 & \\
\hline meso-MIL-125(Ti) & DBT (500 ppm) & TBHP & 10 & 80 & - & - & $(22.9)^{\mathrm{a}}$ & [24] \\
\hline \multirow[t]{2}{*}{ MIL-125(Ti)-L } & DBT (240 ppm) & $\mathrm{H}_{2} \mathrm{O}_{2}$ & 8 & 60 & 30 & 95.3 & 1.0 & \multirow{2}{*}{ [25] } \\
\hline & & TBHP & 8 & 60 & 30 & 44.9 & 0.5 & \\
\hline $\mathrm{COK}-47_{\mathrm{S}}(\mathrm{Ti})$ & DBT (3601 ppm) & TBHP & 2.5 & 60 & 120 & 99 & $(41.1)^{\mathrm{a}}$ & [26] \\
\hline Ti-BDC-180 & DBT (1000 ppm) & $\mathrm{H}_{2} \mathrm{O}_{2}$ & 6 & 60 & 20 & 99.8 & 18.7 & [27] \\
\hline Ti-BDC-A & DBT (500 ppm) & $\mathrm{CHP}$ & 6 & 25 & 10 & 100 & 21.9 & [28] \\
\hline
\end{tabular}

Activity $\left(\mathrm{mmol} \cdot \mathrm{g}^{-1} \cdot \mathrm{h}^{-1}\right)$ : millimole number of converted substrate/(reaction time $\times$ mass of catalyst). ${ }^{\text {a }}$ : kinetic constant $\left[\left(\min ^{-1}\right) \times 10^{-3}\right]$, data from literature.

Recently, Simon Smolders et al. synthesized a new type of Ti-MOF (COK-47) [26]. This material used the composite layer of $\mathrm{TiO}_{6}$ octahedron as two-dimensional secondary structural units to form a three-dimensional framework through a bpdc ${ }^{2-}$ linkers connection. The catalytic results showed that $99 \%$ DBT over COK- $47_{\mathrm{S}}$ was oxidized in $120 \mathrm{~min}$ at $60{ }^{\circ} \mathrm{C}$ by TBHP as an oxidant. Such catalytic performance could be attributed to the presence of many methoxy groups (Me-O-Ti) and open-metal Ti sites. Moreover, the catalyst remained structurally stable after three recycles.

More recently, Sun and coworkers reported that new porous titanium terephthalates with hierarchical porosity (Ti-BDC) and amorphous nature have been successfully synthesized for deep oxidative desulfurization of fuel oil [27]. The catalytic results indicate that Ti-BDC exhibited superior catalytic activity in the ODS reactions of BT, DBT and 4,6-DMDBT than MIL-125(Ti) and meso-MIL-125(Ti), which might be attributed to the introduction of partial mesopores and abundant coordination-unsaturated Ti sites. Especially in the above synthetic system, a novel porous titanium terephthalate (Ti-BDC-A) with more defective Ti sites and higher surface area was produced with the assistance of acetic acid (Figure 1). When the material is used as an ODS catalyst, DBT (500 ppm) in model fuel oil can be completely oxidized in $10 \mathrm{~min}$ at room temperature [28].

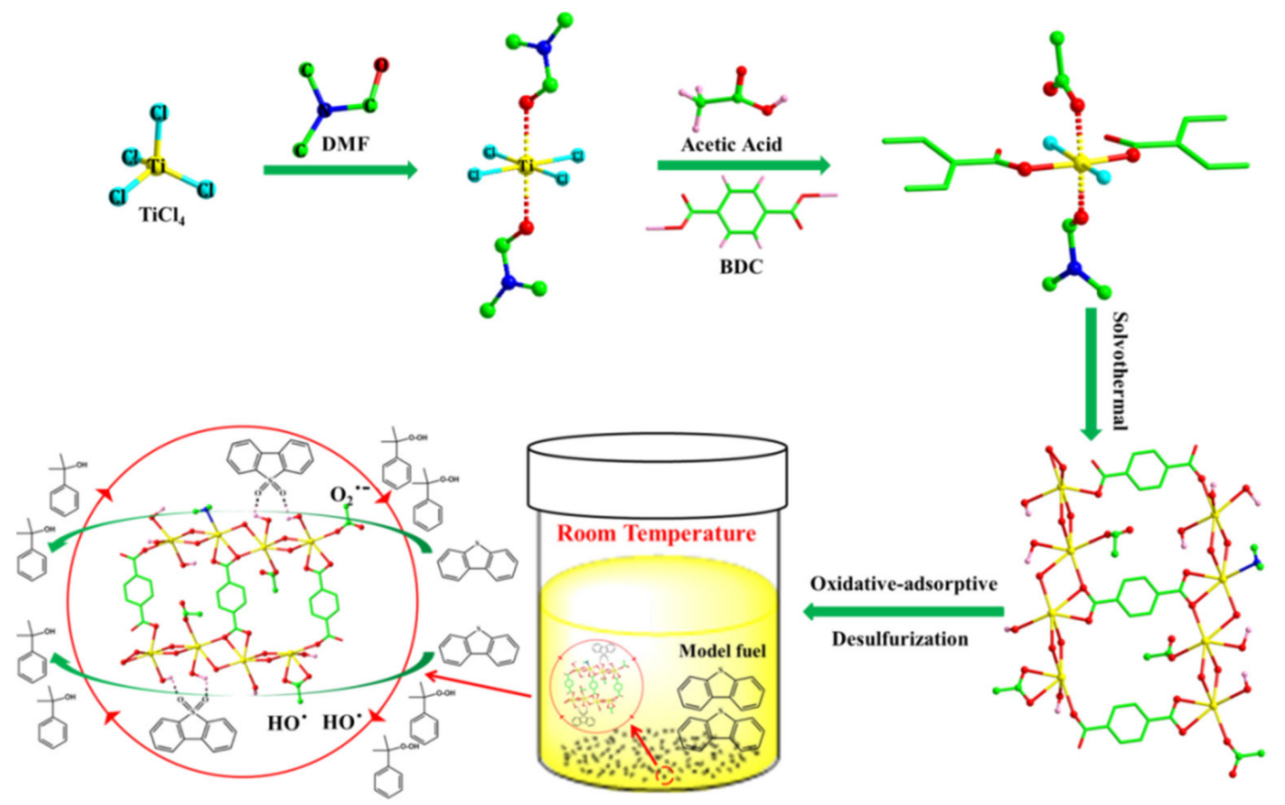

Figure 1. Imaginative diagram of the formation process of Ti-BDC-A and proposed reaction mechanism of the catalytic ODS of DBT over Ti-BDC-A (reproduced from Ref. [28], copyright 2020 American Chemical Society). 


\subsection{Zr-MOFs as ODS Catalysts}

It is generally well known that $\mathrm{Zr}-\mathrm{MOF}$ s possess high structural stability compared with other metal-based MOFs. One example is UiO-66 ( $\mathrm{Zr})$, whose structure composed of $\mathrm{Zr}_{6} \mathrm{O}_{4}\left(\mu_{3}-\mathrm{OH}\right)_{4}$ clusters in coordination with 12 terephthalic acids [29]. In 2015, Granadeiro et al. first reported that $\mathrm{UiO}-66(\mathrm{Zr})$ as a heterogeneous catalyst was used in the ODS of diesel. In this work, UiO-66(Zr) samples were prepared by different synthesis methods and their catalytic ODS performance were evaluated [30]. It is noted that the catalytic performance had a close relationship with the crystallinity degree and linker defects in UiO-66 (Zr). The samples with low crystallinity displayed superior catalytic performance. Meanwhile, the good catalytic activity can be kept in the dual phase catalytic system with $\mathrm{H}_{2} \mathrm{O}_{2}$ as an oxidant and acetonitrile as an extractant for the ODS of model and real diesel. Similarly, some researchers obtained $\mathrm{UiO}-66(\mathrm{Zr})$ with lower crystallinity by shortening the synthesis time, but not surprisingly its reusability was poor [31]. A detailed comparison of catalytic performance over various $\mathrm{Zr}-\mathrm{MOF}$ s is shown in Table 2.

In general, the defects in crystal materials are closely related to their properties. Thus, it is of great importance to prepare the defective crystal materials [32-40]. As for UiO$66(\mathrm{Zr})$, some methods have been developed to fabricate defective UiO-66(Zr). For example, Sun et al. adopted solvent-free synthesis to produce defective UiO-66( $\mathrm{Zr})$ [34]. The catalytic data indicate that $\mathrm{UiO}-66(\mathrm{Zr})$ free with rich defects exhibited much better catalytic activity than UiO-66(Zr) solvent with high crystallinity prepared by conventional solvothermal route in the ODS reactions. Such catalytic performance has a good correlation with the number of Lewis acid sites in $\mathrm{UiO}-66(\mathrm{Zr})$ because the defects that resulted from the loss of organic linkers may promote the formation of Lewis acid sites [35,36]. Based on this study, this research group synthesized defective amino- and nitro-functionalized $\mathrm{UiO}-66(\mathrm{Zr})$ by solvent-free method. The results showed that nitro-functionalized UiO-66(Zr) exhibited excellent catalytic activity in the oxidative desulfurization of DBT and 4,6-DMDBT. The ODS activity could almost be kept after five cycles [17]. The possible reason is that the introduction of electron-withdrawing groups reduces the electron density around $\mathrm{Zr}$ and enhances its electron-withdrawing ability $[37,38]$. On the other hand, most of MOFs are microporous materials, which would limit the mass transfer of reactants and hinder the accessibility of catalytic active sites in the pores [41]. For this, Hao et al. synthesized hierarchical porous $\mathrm{UiO}-66(\mathrm{Zr})(\mathrm{HP}-\mathrm{UiO}-66(\mathrm{Zr})$ and evaluated its ODS performance. The results showed that HP-UiO-66( $\mathrm{Zr}$ ) could complete the oxidation of DBT and 4,6-DMDBT at room temperature at a low oxidant dosage $(\mathrm{O} / \mathrm{S}=4)$ [42].

Based on the structure of $\mathrm{UiO}-66(\mathrm{Zr})$, bimetal-centered $\mathrm{UiO}-66(\mathrm{Zr})$ materials were also prepared. Sun et al. firstly reported $\mathrm{Ti}-\mathrm{UiO}-66(\mathrm{Zr})$ obtained by ion-exchange method for ODS reactions [43]. It is well known that Ti ions have stronger oxidation ability than $\mathrm{Zr}$ ions [44]. Consequently, Ti-UiO-66(Zr) showed better catalytic ODS performance than the parent $\mathrm{UiO}-66(\mathrm{Zr})$. In addition, Ye et al. prepared Hf-incorporated UiO-66(Zr) under solvent-free conditions [45]. In the structure of this material, $0.7 \mathrm{Zr}$ atoms are replaced by $\mathrm{Hf}$ atoms to form $\mathrm{Zr}$-Hf-oxo clusters with a considerable number of $\mathrm{Zr} / \mathrm{Hf}-\mathrm{OH}$ active sites (Figure 2). The obtained catalyst may complete the oxidation of 4,6-DMDBT (1000 ppm) from model oil within $15 \mathrm{~min}$ at room temperature. Theoretical studies indicate that the exposed Hf-OH centers can easily react with $\mathrm{H}_{2} \mathrm{O}_{2}$ to form $\mathrm{Hf}-\mathrm{OOH}$ intermediates and thus control the reactivity.

Besides UiO-66(Zr), other research works about Zr-MOFs involve two-dimensional layered UMCM-309(Zr) and three-dimensional porous MOF-808( $\mathrm{Zr})$ with the same secondary structure units $\left[\mathrm{Zr}_{6} \mathrm{O}_{4}(\mathrm{OH})_{4}(-\mathrm{COO})_{6}\right]^{6+}$. The study from $\mathrm{Fu}$ et al. showed that MOF-808(Zr) had better ODS activity than UMCM-309(Zr). Further, the catalytic activity over MOF-808( $\mathrm{Zr}$ ) can be greatly improved after the removal of partial formic acid in its structure because more open metal sites are generated [46,47]. Some studies suggest that the order of catalytic ODS activity over different $\mathrm{Zr}-\mathrm{MOF}$ is MOF-808(Zr) $>$ UiO$67(\mathrm{Zr})>\mathrm{NU}-1000(\mathrm{Zr})>\mathrm{UiO}-66(\mathrm{Zr})$, which coincides with the number of Lewis acid sites (Figure 3) [48,49]. Moreover, the studies on NU-1000(Zr) and MOF-808(Zr) revealed that 
mesoporous structure and Lewis acidity played an important role on the ODS activity of Zr-MOF materials [50-52].
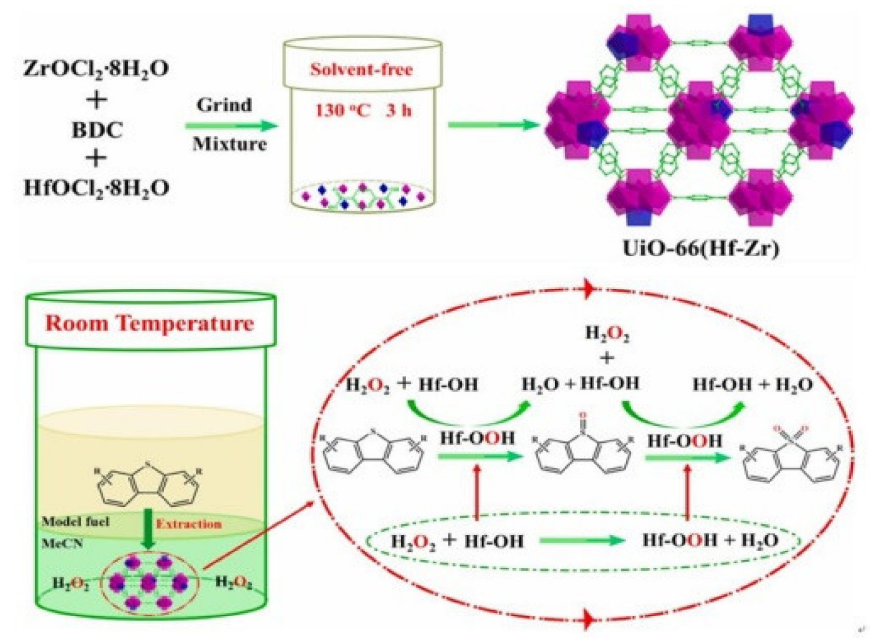

Figure 2. Schematic illustration about the synthetic process of UiO-66 $(0.13 \mathrm{Hf}-\mathrm{Zr})$ and proposed ODS reaction mechanism over UiO-66(0.13Hf-Zr) (adapted from Ref. [45], copyright 2021 Elsevier).

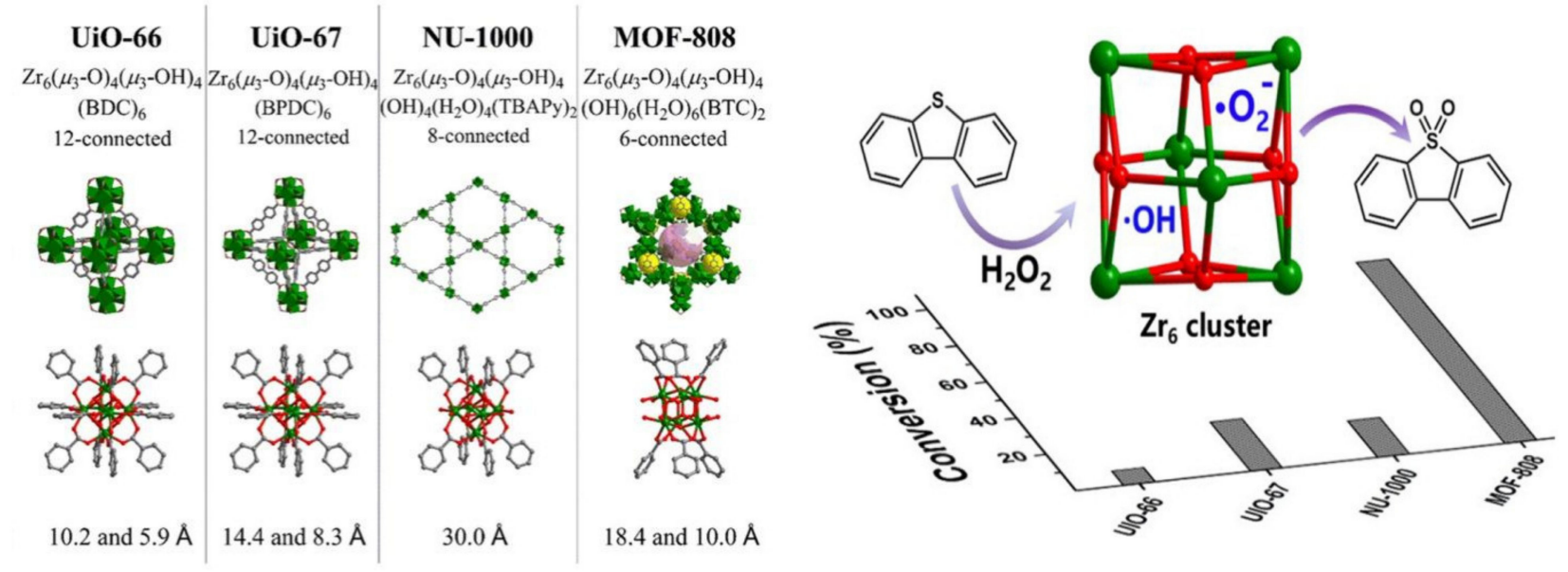

Figure 3. The structure of various Zr-MOFs and their catalytic oxidation performance (adapted from Ref. [48], copyright 2019 American Chemical Society).

Table 2. Comparison of catalytic performance over various Zr-MOFs in the ODS reactions of model fuel oil.

\begin{tabular}{|c|c|c|c|c|c|c|c|c|}
\hline Catalyst & $\begin{array}{l}\text { Substrate } \\
\text { (S Content) }\end{array}$ & Oxidant & $\begin{array}{c}\text { O/S } \\
\text { Ratio }\end{array}$ & $\begin{array}{l}\text { Temp. } \\
\left({ }^{\circ} \mathrm{C}\right)\end{array}$ & $\begin{array}{l}\text { Time } \\
(\mathrm{min})\end{array}$ & $\begin{array}{l}\text { Sulfur } \\
\text { Removal } \\
(\%)\end{array}$ & $\begin{array}{l}\text { Activity } \\
\left(\mathrm{mmol}^{\prime} \mathrm{g}^{-1} \cdot \mathrm{h}^{-1}\right)\end{array}$ & Ref. \\
\hline UiO-66(Zr) & \multirow{4}{*}{$\begin{array}{c}\text { DBT, 4-MDBT } \\
\text { and 4,6-DMDBT } \\
\text { (500 ppm for each) }\end{array}$} & \multirow{4}{*}{$\mathrm{H}_{2} \mathrm{O}_{2}$} & \multirow{4}{*}{12} & \multirow{4}{*}{50} & \multirow{4}{*}{30} & 99.6 & & \multirow{4}{*}[30]{} \\
\hline $\mathrm{UiO}-66(\mathrm{Zr})_{\mathrm{mod}}$ & & & & & & 71.2 & & \\
\hline $\mathrm{UiO}-66(\mathrm{Zr})_{\mathrm{HCl}, \bmod }$ & & & & & & 59.9 & - & \\
\hline $\mathrm{UiO}-66(\mathrm{Zr})_{\mathrm{HCl}}$ & & & & & & 36.9 & & \\
\hline $\mathrm{UiO}-66(\mathrm{Zr})-1 \mathrm{~h}$ & DBT (1000 ppm) & $\mathrm{H}_{2} \mathrm{O}_{2}$ & $\approx 11$ & 60 & 60 & 97 & 8.5 & [31] \\
\hline \multirow[t]{2}{*}{$\mathrm{UiO}-66(\mathrm{Zr})$-solvent } & DBT (1000 ppm) & $\mathrm{H}_{2} \mathrm{O}_{2}$ & 6 & 60 & 120 & 80.5 & 2.5 & \multirow{4}{*}{ [34] } \\
\hline & 4,6-DMDBT (500 ppm) & & & & & 52.5 & 0.82 & \\
\hline \multirow[t]{2}{*}{$\mathrm{UiO}-66(\mathrm{Zr})$-free } & DBT (1000 ppm) & $\mathrm{H}_{2} \mathrm{O}_{2}$ & 6 & 60 & 120 & 99.6 & 3.1 & \\
\hline & 4,6-DMDBT (500 ppm) & & & & & 98.1 & 1.5 & \\
\hline $\mathrm{UiO}-66(\mathrm{Zr})$ & DBT (500 ppm) & $\mathrm{H}_{2} \mathrm{O}_{2}$ & 12 & 60 & 150 & 100 & - & [36] \\
\hline
\end{tabular}


Table 2. Cont.

\begin{tabular}{|c|c|c|c|c|c|c|c|c|}
\hline Catalyst & $\begin{array}{l}\text { Substrate } \\
\text { (S Content) }\end{array}$ & Oxidant & $\begin{array}{c}\mathrm{O} / \mathrm{S} \\
\text { Ratio }\end{array}$ & $\begin{array}{l}\text { Temp. } \\
\left({ }^{\circ} \mathrm{C}\right)\end{array}$ & $\begin{array}{l}\text { Time } \\
\text { (min) }\end{array}$ & $\begin{array}{c}\text { Sulfur } \\
\text { Removal } \\
(\%)\end{array}$ & $\begin{array}{c}\text { Activity } \\
\left(\mathrm{mmol}^{\prime} \mathrm{g}^{-1} \cdot \mathrm{h}^{-1}\right)\end{array}$ & Ref. \\
\hline $\mathrm{UiO}-66(\mathrm{Zr})-\mathrm{NO}_{2}$-green & $\begin{array}{c}\text { DBT (1000 ppm) } \\
\text { 4,6-DMDBT (500 ppm) }\end{array}$ & $\mathrm{H}_{2} \mathrm{O}_{2}$ & 6 & 60 & 30 & $\begin{array}{l}99.6 \\
99.6\end{array}$ & & \\
\hline $\mathrm{UiO}-66(\mathrm{Zr})-\mathrm{NH}_{2}$-green & $\begin{array}{c}\text { DBT (1000 ppm) } \\
\text { 4,6-DMDBT (500 ppm) }\end{array}$ & $\mathrm{H}_{2} \mathrm{O}_{2}$ & 6 & 60 & 30 & $\begin{array}{l}62.6 \\
45.6\end{array}$ & - & [17] \\
\hline $\mathrm{UiO}-66(\mathrm{Zr})$-green & $\begin{array}{c}\text { DBT (1000 ppm) } \\
\text { 4,6-DMDBT (500 ppm) }\end{array}$ & $\mathrm{H}_{2} \mathrm{O}_{2}$ & 6 & 60 & 30 & $\begin{array}{l}90.3 \\
94.2\end{array}$ & & \\
\hline $\begin{array}{l}\mathrm{UiO}-66(\mathrm{Zr})-\mathrm{S} 1 \\
\mathrm{UiO}-66(\mathrm{Zr})-\mathrm{MW} 2\end{array}$ & $\begin{array}{l}\text { 1-BT, DBT, 4-MDBT } \\
\text { and 4,6-DMDBT } \\
\text { (500 ppm for each) }\end{array}$ & $\mathrm{H}_{2} \mathrm{O}_{2}$ & 13 & 50 & 180 & $\begin{array}{c}99.5 \\
96\end{array}$ & - & [39] \\
\hline $\begin{array}{l}\mathrm{UiO}-66(\mathrm{Zr})-\mathrm{ZrCl}_{4} \\
\mathrm{UiO}-66(\mathrm{Zr})\end{array}$ & $\begin{array}{l}\text { BT, DBT, 4-MDBT } \\
\text { and 4,6-DMDBT } \\
\text { (500 ppm for each) }\end{array}$ & $\mathrm{H}_{2} \mathrm{O}_{2}$ & 13 & 50 & 60 & $\begin{array}{l}97 \\
62\end{array}$ & - & [40] \\
\hline HP-UiO-66(Zr) & $\begin{array}{c}\text { DBT }(1000 \text { ppm }) \\
\text { 4,6-DMDBT } \\
(1000 \text { ppm })\end{array}$ & $\mathrm{H}_{2} \mathrm{O}_{2}$ & 4 & 30 & $\begin{array}{l}30 \\
60\end{array}$ & $\begin{array}{l}94.3 \\
99.3\end{array}$ & $\begin{array}{l}19.6 \\
10.3\end{array}$ & [42] \\
\hline $\begin{array}{l}\text { Ti-UiO-66-D } \\
\text { UiO-66-D } \\
\text { Ti-UiO-66-H } \\
\text { UiO-66-H }\end{array}$ & DBT (1000 ppm) & $\begin{array}{l}\mathrm{H}_{2} \mathrm{O}_{2} \\
\mathrm{H}_{2} \mathrm{O}_{2}\end{array}$ & 6 & 60 & 120 & $\begin{array}{c}91.7 \\
50.7 \\
66.3 \\
5.6\end{array}$ & $\begin{array}{c}2.9 \\
1.6 \\
2.1 \\
0.17\end{array}$ & [43] \\
\hline UiO-66(0.13Hf-Zr) & $\begin{array}{c}\text { DBT (1000 ppm) } \\
\text { BT (1000 ppm) } \\
\text { 4,6-DMDBT } \\
\text { (1000 ppm) }\end{array}$ & $\mathrm{H}_{2} \mathrm{O}_{2}$ & 4 & 30 & 15 & $\begin{array}{l}99.8 \\
70.8 \\
100\end{array}$ & $\begin{array}{c}17.5 \\
- \\
-\end{array}$ & [45] \\
\hline $\mathrm{UiO}-66(\mathrm{Zr})$ & DBT (1000 ppm) & $\mathrm{H}_{2} \mathrm{O}_{2}$ & 5 & 50 & 5 & 8.8 & & \\
\hline UiO-67(Zr) & DBT (1000 ppm) & $\mathrm{H}_{2} \mathrm{O}_{2}$ & 5 & 50 & 5 & 20.8 & - & {$[48]$} \\
\hline NU-1000(Zr) & DBT (1000 ppm) & $\mathrm{H}_{2} \mathrm{O}_{2}$ & 5 & 50 & 5 & 11.1 & - & [48] \\
\hline MOF-808(Zr) & $\begin{array}{l}\text { DBT (1000 ppm) } \\
\text { DBT (1000 ppm) }\end{array}$ & $\begin{array}{l}\mathrm{H}_{2} \mathrm{O}_{2} \\
\mathrm{H}_{2} \mathrm{O}_{2}\end{array}$ & $\begin{array}{l}5 \\
6\end{array}$ & $\begin{array}{l}50 \\
60\end{array}$ & $\begin{array}{c}5 \\
180\end{array}$ & $\begin{array}{l}100 \\
100\end{array}$ & 2.6 & \\
\hline NU-1000(Zr) & $\begin{array}{c}\text { BT (500 ppm) } \\
\text { 3-MDBT (500 ppm) } \\
\text { 4,6-DMDBT (500 ppm) }\end{array}$ & & & & & $\begin{array}{l}\approx 62 \\
\approx 81 \\
67.6\end{array}$ & $\begin{array}{l}- \\
- \\
-\end{array}$ & [50] \\
\hline UMCM-309(Zr) & $\begin{array}{c}\text { DBT (4319 ppm) } \\
\text { BT (4378 ppm) } \\
\text { 4,6-DMDBT }\end{array}$ & TBHP & 2.5 & 60 & 480 & $\begin{array}{l}96 \\
49 \\
30\end{array}$ & $\begin{array}{c}2.5 \\
1.3 \\
0.79\end{array}$ & \\
\hline MOF-808(Zr)-M & $\begin{array}{c}\text { (4303 ppm) } \\
\text { BT, DBT and } \\
\text { 4,6-DMDBT } \\
\text { (500 ppm for each) }\end{array}$ & TBHP & 2.5 & 60 & 60 & 68 & 9.2 & [46] \\
\hline MOF-808(Zr)-H & $\begin{array}{c}\text { DBT (1000 ppm) } \\
\text { BT (1000 ppm) } \\
\text { 4,6-DMDBT (500 ppm) }\end{array}$ & $\mathrm{CHP}$ & 3 & 50 & 20 & $\begin{array}{l}93 \\
\approx 34 \\
\approx 17\end{array}$ & $\begin{array}{c}17.4 \\
- \\
-\end{array}$ & [52] \\
\hline
\end{tabular}

\subsection{Other Metal-Centered MOFs as ODS Catalysts}

The other metal-centered MOFs mainly include the studies of V-MOFs, Co-MOFs and MIL-101(Fe/Cr) for ODS reactions. A detailed comparison of catalytic performance over other metal-centered MOFs in the ODS reactions of model fuel oil is shown in Table 3.

MIL-47(V) is the first example of non-Zr- and Ti-based MOFs for ODS reactions. In this work, the catalytic performance of MIL-47(V) was compared with that of MIL-125(Ti) by the oxidation reactions of T, BT and DBT [53]. The results show that MIL-47(V) exhibited better catalytic ODS performance than MIL-125(Ti) in the oxidation of DBT. Meanwhile, MIL-47(V) is more suitable for the catalytic oxidation of DBT at relatively low reaction temperatures, which should be related to the pore size of the material. Under the same reaction conditions, the removal efficiency of BT over MIL- $47(\mathrm{~V})$ is not as good as that of DBT. A reasonable explanation is that the electron density of sulfur atoms in DBT is higher, while the sulfur 
species with higher electron density have higher catalytic activity [54,55]. Notably, MIL$47(\mathrm{~V})$ exhibited unusual catalytic activity in the oxidation of thiophene, suggesting that metal centers in MOFs have a great influence on the ODS reactions. Although the catalytic ODS performance of MIL-47(V) is better than that of MIL-125(Ti), its structural stability is poor.

Another interesting study about V-MOFs is the study on MFM-300(V). Li et al. found that MFM-300(V) can carry out the ODS reaction by ambient air as the oxidant, and the removal of DBT and 4,6-DMDBT reached $99.6 \%$ and $98.1 \%$, respectively [56]. The bridging oxygen atoms in the structure exist on the corner of pores and make MFM-300(V) surface of pores locally electron-rich, which is conducive to capturing protons from hydrocarbons and activating oxygen in the air [57].

Masoomi et al. reported that Co-MOF materials (TMU-10 and TMU-12) were successfully synthesized and their catalytic performance in ODS reactions was evaluated [58]. The removal of DBT (500 ppm) over TMU-12(Co) was $75.2 \%$ at $60^{\circ} \mathrm{C}$. Additionally, Abazari et al. studied the catalytic ODS performance over another type of Co-MOF $\left(\mathrm{NH}_{2}-\mathrm{TMU}-53\right)$. The results showed that the sulfur content in a model oil for DBT removal can be reduced from $500 \mathrm{ppm}$ to $103 \mathrm{ppm}$ at $60^{\circ} \mathrm{C}$ after $2 \mathrm{~h}$ [59]. Meanwhile, it is noted that the introduction of amino functional groups may significantly improve the adsorption ability for DBT, and the oxidation rate of DBT increased with adsorption amount.

MIL-101 is an important class of MOFs, which generally possess high surface area and large pore openings. Adrián Gómez-Paricio et al. first investigated the catalytic performance of MIL-101(Fe) and MIL-101(Cr) in ODS of DBT with oxygen as the oxidant [60]. During the reaction, an obvious induction period of $6 \mathrm{~h}$ was observed. Further studies disclosed that the induction period of the reaction was related to solvent diffusion and the formation of the first reactive oxygen species. The catalytic results showed that MIL$101(\mathrm{Cr})$ had better catalytic activity and cycle stability than MIL-101(Fe). Subsequently, the catalytic performance of functionalized MIL-101(Cr) was also studied. It was found that nitro-functionalized MIL-101(Cr) had better ODS activity for DBT in fuel oil [61], which is in agreement with the case of functionalized $\mathrm{UiO}-66(\mathrm{Zr})$.

Table 3. Comparison of catalytic performance over other metal-centered MOFs in the ODS reactions of model fuel oil.

\begin{tabular}{|c|c|c|c|c|c|c|c|c|}
\hline Catalyst & $\begin{array}{l}\text { Substrate } \\
\text { (S Content) }\end{array}$ & Oxidant & $\begin{array}{c}\mathrm{O} / \mathrm{S} \\
\text { Ratio }\end{array}$ & $\begin{array}{l}\text { Temp. } \\
\left({ }^{\circ} \mathrm{C}\right)\end{array}$ & $\begin{array}{l}\text { Time } \\
(\min )\end{array}$ & $\begin{array}{c}\text { Sulfur } \\
\text { Removal } \\
(\%)\end{array}$ & $\begin{array}{c}\text { Activity } \\
\left(\mathrm{mmol}^{\prime} \mathrm{g}^{-1} \cdot \mathrm{h}^{-1}\right)\end{array}$ & Ref. \\
\hline MIL-47(V) & $\begin{array}{c}\text { DBT (15691 ppm) } \\
\text { T (7165 ppm) } \\
\text { BT (11428 ppm) }\end{array}$ & TBHP & 2.15 & 80 & - & - & $\begin{array}{l}(29)^{\mathrm{a}} \\
(1.3)^{\mathrm{a}} \\
(9.9)^{\mathrm{a}}\end{array}$ & [53] \\
\hline TMU-10(Co) & DBT (500 ppm) & ТВНР & 3 & 60 & 360 & 40.5 & 0.17 & \\
\hline TMU-12(Co) & DBT (500 ppm) & TBHP & 3 & 60 & 360 & 75.2 & 0.32 & [58] \\
\hline $\mathrm{NH}_{2}-\mathrm{TMU}(\mathrm{Co})-53$ & DBT (500 ppm) & $\mathrm{H}_{2} \mathrm{O}_{2}$ & 3 & 60 & 120 & 79.4 & $(10.6)^{a}$ & [59] \\
\hline MIL-101(Cr) & DBT (1534 ppm) & $\mathrm{O}_{2}$ & - & 120 & 1260 & 99.6 & - & [60] \\
\hline MIL-101(Cr)-NO & $\begin{array}{l}\text { DBT (200 ppm) } \\
\text { DBT (200 ppm) }\end{array}$ & $\mathrm{O}_{2}$ & - & 140 & $\approx 270$ & $\begin{array}{c}\approx 100 \\
99.6\end{array}$ & - & [61] \\
\hline MFM-300(V) & $\begin{array}{c}\text { BT (200 ppm) } \\
\text { 4,6-DMDBT (200 ppm) }\end{array}$ & Air & - & 120 & 300 & $\begin{array}{l}18.0 \\
98.1\end{array}$ & - & [56] \\
\hline
\end{tabular}

a: kinetic constant $\left[\left(\mathrm{min}^{-1}\right) \times 10^{-3}\right]$, data from literature.

\section{Composites of MOFs and Additional Active Phases as ODS Catalysts}

Although MOFs generally have the advantages of high surface area, rich porosity and varied pore structures for catalytic reactions, it is a fact that the number of catalytic active sites in MOFs is limited because most metal centers are in a state of coordination saturation. To remedy this shortcoming, some composite catalysts of MOFs and additional active phases have been designed and synthesized by various strategies. The studied MOFs mostly referred to the MIL family, Zr-MOFs and MOF-199 with good structural stability. 
The active phases were mainly focused on various types of polyoxometalates and some metal oxides.

\subsection{Composites of MOFs and Polyoxometalates}

Polyoxometalates (POMs) have been widely studied as the active centers of ODS catalysts because their acidic and redox properties can be effectively designed and controlled through changing their compositions and structures at atomic or molecular scale $[62,63]$. However, it is well known that POMs are easily soluble in organic medium, which is not beneficial for the recycling and reuse of heterogeneous catalysts. Thus, the composites of encapsulating POMs into MOFs can be an efficient approach to solve this problem. Table 4 shows a detailed comparison of catalytic performance over the composites of MOFs and POMs in the ODS reactions of model fuel oil.

One of the research focuses is the synthesis and catalytic ODS performance of the composite of POMs and MOFs from the MIL family. Hu et al. first reported the encapsulation of phosphotungstic acid (PTA) into the cages of MIL-101(Cr) by using the strategy of "bottle around ship" under static conditions [64]. The obtained material exhibited the order of oxidation activity (DBT > 4,6-DMDBT > BT) for different sulfur compounds. After four consecutive reaction cycles, the catalytic performance decreased by about $4 \%$ and PTA loading in the composite reduced by about $5 \%$, indicating that such encapsulation could greatly inhibit the loss of PTA into organic medium. Based on this methodology, some similar POMs [65-68] were also used as active centers encapsulated in the cages of MIL-101(Cr). For instance, Ribeiro et al. utilized $\left[\mathrm{Tb}\left(\mathrm{PW}_{11} \mathrm{O}_{39}\right)_{2}\right]^{11-}$ (abbreviated as $\left.\mathrm{Tb}\left(\mathrm{PW}_{11}\right)_{2}\right)$ and $\mathrm{TBA}_{3} \mathrm{PW}_{12} \mathrm{O}_{40}$ (abbreviated as $\mathrm{PW}_{12}$ ) as the active centers of composite catalysts for ODS reactions $[65,66]$. The catalytic results showed that DBT in model oil was almost completely oxidized over both catalysts and could be reused well. The difference is that the former uses acetonitrile as the extractant and the latter is ionic liquids $\mathrm{BMIPF}_{6}$. It was found that ionic liquids can promote the generation of reactive oxygen species and avoid the decomposition of $\mathrm{PW}_{12}$, which is an effective co-catalyst. In addition to the abovementioned Keggin-type POMs, the Weakley-type $\mathrm{Na}_{7} \mathrm{H}_{2} \mathrm{LaW}_{10} \mathrm{O}_{36}$ (abbreviated as $\mathrm{LaW}_{10}$ ) was also investigated because its molecular size matches well with the window size of MIL-101(Cr) [69]. Lu et al. coated and dispersed it into the nanocages of MIL-101(Cr) at the single molecular level (Figure 4) [70]. The resultant material exhibited excellent reusability due to the limiting effect of the coordination interaction from $\mathrm{Cr} \cdots \mathrm{O}=\mathrm{W}$ bonds and good size matching. Notably, when phosphotungstic acid $\left(\mathrm{H}_{3} \mathrm{PW}_{12} \mathrm{O}_{40}, \mathrm{PTA}\right)$ was used as the active species, $\mathrm{NH}_{2}$-functionalized MOFs could be considered to make the composite catalysts. Due to the electrostatic interaction between the $\left[\mathrm{PW}_{12} \mathrm{O}_{40}\right]^{3-}$ ion and $-\mathrm{NH}^{3+}$ groups from $\mathrm{NH}_{2}-\mathrm{MOFs}$, the structural stability of PTA@MOFs was enhanced and PTA loading increased. The typical examples are the combination of POMs with $\mathrm{NH}_{2}$-MIL-53(Al) and $\mathrm{NH}_{2}$-MIL-101(Cr) [71-79].

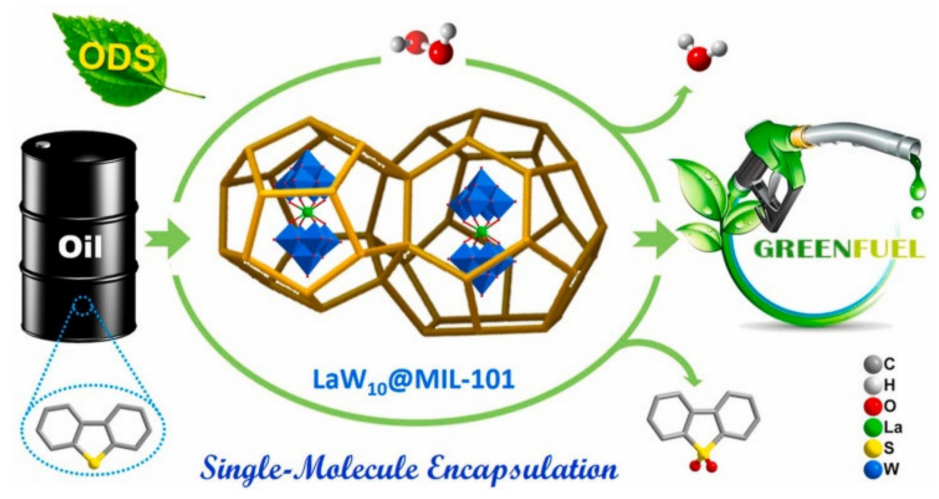

Figure 4. The LaW 10 guests were dispersed homogeneously in MIL-101(Cr) nanocages at molecular level and used as ODS catalyst (reproduced from Ref. [70], copyright 2021 Elsevier). 
Another research hot spot is the combination of POMs and MOF-199(Cu). MOF-199(Cu) is welcomed mainly because its pore size closely matches with the size of POMs [80,81]. Rafiee et al. first synthesized three composites of POMs and MOF-199(Cu) and demonstrated their potential in ODS reactions [82]. Further, a series of such composites (including, but not limited to, POM@MOF-199@MCM-41, C-POM@MOF-199@MCM-41, HPA@MOF199@CA, CNTs@MOF-199- $\mathrm{Mo}_{16} \mathrm{~V}_{2}$ ) were prepared for ODS reactions with $\mathrm{O}_{2}$ as the oxidant [83-91]. The catalytic results indicated that the combination of POM and MOF199(Cu)@MCM-41 might be helpful for the enhancement of ODS performance under the reaction condition of $\mathrm{O}_{2}$ as the oxidant. Based on the combination of the same active species with different MOFs, Wang et al. made a comparison on the catalytic ODS activity of PTA@MIL-100(Fe), PTA@UiO-66(Zr), and PTA@ZIF-8(Zn). The results suggested that MOFs with large window size could be more suitable for the encapsulation of active species [92]. In addition, to facilitate the recovery of catalyst, Si-Wen Li et al., synthesized $\mathrm{Fe}_{3} \mathrm{O}_{4} @ M O F-P M o W(F e M P, \mathrm{M}=\mathrm{Cr}, \mathrm{Cu}, \mathrm{Zr}$ ) with magnetism by the one-pot method [19]. It has been proposed that this kind of catalyst has a unique spinous structure similar to the virus, which is beneficial for enhancing the catalytic performance by increasing the contact area with sulfur substrate (Figure 5).

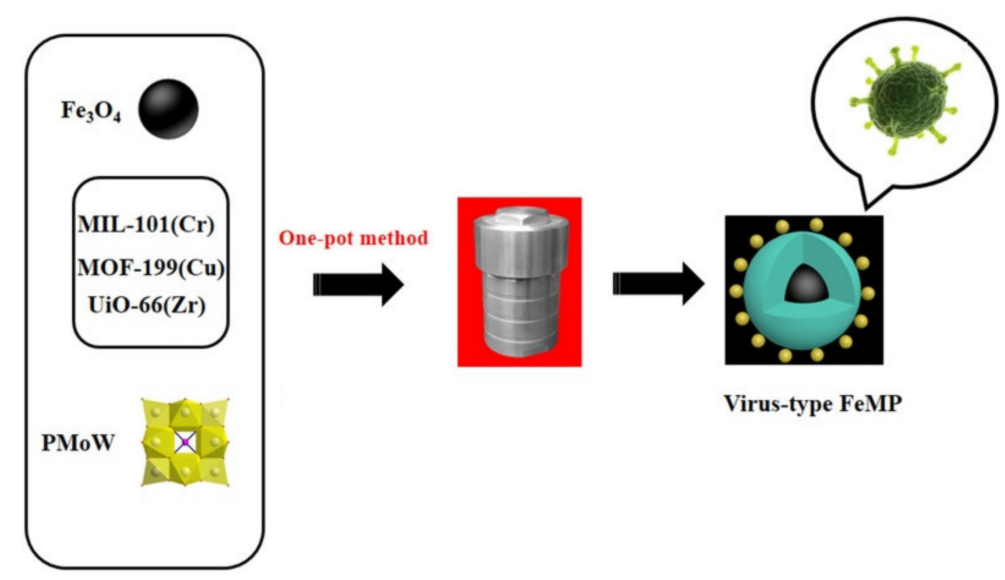

Figure 5. The scheme route to synthesis spinosus FeMP catalyst (reproduced from Ref. [19], copyright 2021 Elsevier).

The other cases mainly involved the composites of POMs and Zr-MOFs, such as UiO66(Zr) [92-97], UiO-67(Zr) [98] and MOF-808(Zr) [99]. Zhang and coworkers encapsulated $\mathrm{H}_{3} \mathrm{PMo}_{12} \mathrm{O}_{40}$ (PMA) into the pores of $\mathrm{UiO}-66(\mathrm{Zr})$ and evaluated its catalytic performance by the oxidation of DBT (500 ppm) in model oil by using TBHP as an oxidant [93]. The excellent catalytic performance was attributed to the synergistic effect between $\mathrm{UiO}-66(\mathrm{Zr})$ and PMA. The lack of lattice oxygen and electron transfer led to the easier generation of oxygen vacancies and $\mathrm{Mo}^{5+}$ on PMA@UiO-66(Zr), which can promote the formation of active free radicals and thus improve its ODS performance. In addition, it has been demonstrated that unsaturated metal sites or defect sites in MOFs are closely related to the catalytic performance of materials [26,31]. For example, Chang et al. introduced thiourea and 1-butyl-3-methylimidazolium chloride $([\mathrm{Bmim}] \mathrm{Cl})$ into the synthetic system of PMA@UiO-66( $\mathrm{Zr})$ to construct more unsaturated metal sites in UiO-66(Zr). As a result, the enhancement of catalytic ODS performance was observed [94]. Sun et al. reported that UiO-66(Zr) with abundant defect sites can be synthesized by the solvent-free method [34]. Based on this work, a composite material of HPW and UiO-66(Zr) (PW/UiO-66(Zr)-green) was produced (Figure 6) [96]. It should be emphasized that the catalyst synthesized by this method possesses hierarchical pores and double active sites and displays excellent catalytic activity to oxidize DBT and 4,6-DMDBT at room temperature when $\mathrm{H}_{2} \mathrm{O}_{2}$ is used as the oxidant. 


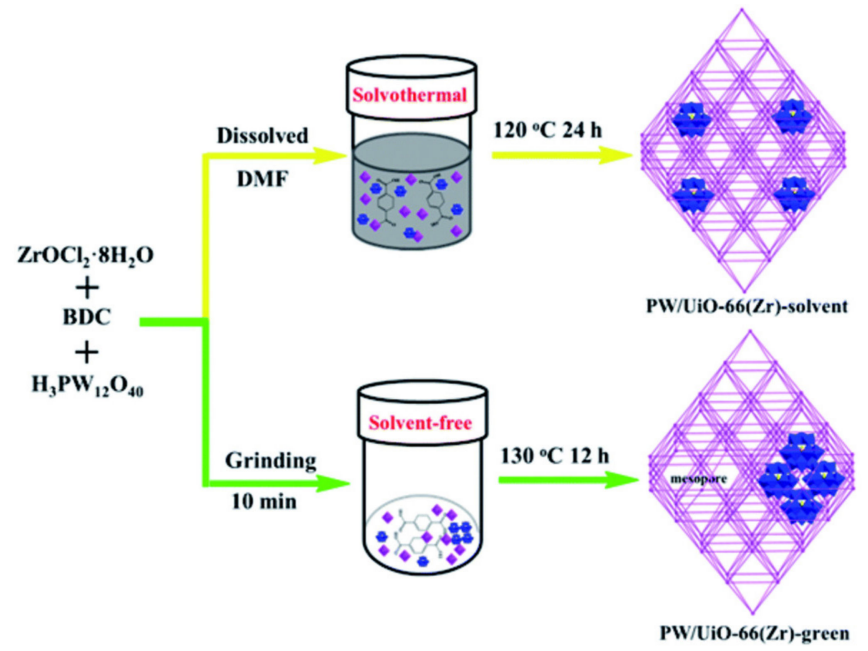

Figure 6. Diagram of the synthetic processes of $\mathrm{PW} / \mathrm{UiO}-66(\mathrm{Zr})$-solvent and $\mathrm{PW} / \mathrm{UiO}-66(\mathrm{Zr})$-green (reproduced from Ref. [96], copyright 2020 Royal Society of Chemistry).

Table 4. Comparison of catalytic performance over the composites of MOFs and POMs in the ODS reactions of model fuel oil.

\begin{tabular}{|c|c|c|c|c|c|c|c|c|}
\hline Catalyst & $\begin{array}{l}\text { Substrate } \\
\text { (S Content) }\end{array}$ & Oxidant & $\begin{array}{l}\text { O/S } \\
\text { Ratio }\end{array}$ & $\begin{array}{l}\text { Temp. } \\
\left({ }^{\circ} \mathrm{C}\right)\end{array}$ & $\begin{array}{l}\text { Time } \\
(\mathrm{min})\end{array}$ & $\begin{array}{l}\text { Sulfur } \\
\text { Removal } \\
(\%)\end{array}$ & $\begin{array}{l}\text { Activity } \\
\left(\mathrm{mmol}^{\prime} \mathrm{g}^{-1} \cdot \mathrm{h}^{-1}\right)\end{array}$ & Ref. \\
\hline 50\%PTA@MIL-101(Cr) & DBT ( $\approx 912$ ppm) & $\mathrm{H}_{2} \mathrm{O}_{2}$ & 50 & 45 & 180 & 91 & - & [64] \\
\hline $\begin{array}{c}\mathrm{Tb}\left(\mathrm{PW}_{11}\right)_{2} @ \mathrm{MIL}- \\
\text { 101(Cr) }\end{array}$ & $\begin{array}{c}\text { 1-BT (500 ppm) } \\
\text { DBT (500 ppm) } \\
\text { 4,6-DMDBT (500 ppm) }\end{array}$ & $\mathrm{H}_{2} \mathrm{O}_{2}$ & 30 & 50 & 120 & $\begin{array}{c}95 \\
100 \\
96\end{array}$ & $\begin{array}{l}0.064 \\
0.067 \\
0.065\end{array}$ & [66] \\
\hline PW $12 @ M I L-101(C r)$ & $\begin{array}{l}\text { DBT (500 ppm) } \\
\text { 1-BT (500 ppm) }\end{array}$ & $\mathrm{H}_{2} \mathrm{O}_{2}$ & 10 & 50 & 60 & $\begin{array}{l}100 \\
98.6\end{array}$ & $\begin{array}{c}0.32 \\
0.088\end{array}$ & [65] \\
\hline PW 9 @MIL-101(Cr) & $\begin{array}{c}\text { DBT (500 ppm) } \\
\text { 4,6-DMDBT (500 ppm) } \\
\text { 1-BT (500 ppm) }\end{array}$ & $\mathrm{H}_{2} \mathrm{O}_{2}$ & $\approx 89$ & 50 & 60 & $\begin{array}{l}100 \\
98.9 \\
100\end{array}$ & $\begin{array}{l}0.089 \\
0.088\end{array}$ & [67] \\
\hline PW 11 Zn@MIL-101(Cr) & $\begin{array}{c}\text { DBT (500 ppm) } \\
\text { 4,6-DMDBT (500 ppm) }\end{array}$ & $\mathrm{H}_{2} \mathrm{O}_{2}$ & 8 & 50 & 120 & $\begin{array}{l}100 \\
100\end{array}$ & - & [68] \\
\hline LaW $_{10} @$ MIL-101(Cr) & $\begin{array}{c}\text { BT (500 ppm) } \\
\text { DBT (500 ppm) } \\
\text { 4,6-DMDBT (500 ppm) } \\
\text { BT (950 ppm) }\end{array}$ & $\mathrm{H}_{2} \mathrm{O}_{2}$ & $\begin{array}{c}6 \\
10\end{array}$ & 60 & $\begin{array}{l}180 \\
240\end{array}$ & $\begin{array}{l}87.4 \\
99.1 \\
94.5 \\
70.5\end{array}$ & $\begin{array}{l}0.40 \\
0.45 \\
0.43\end{array}$ & [70] \\
\hline PTA@MIL-101(Cr)-NH 2 & $\begin{array}{c}\text { DBT (950 ppm) } \\
\text { 4,6-DMDBT (950 ppm) }\end{array}$ & $\mathrm{H}_{2} \mathrm{O}_{2}$ & $\begin{array}{c}4 \\
10\end{array}$ & 50 & $\begin{array}{c}60 \\
240\end{array}$ & $\begin{array}{l}100 \\
88.2\end{array}$ & $(76)^{\mathrm{a}}$ & [71] \\
\hline 2PTA/NH $2-\mathrm{MOF}(\mathrm{Al})$ & DBT (500 ppm) & $\mathrm{H}_{2} \mathrm{O}_{2}$ & 20 & 65 & 240 & $\approx 100$ & 0.39 & [72] \\
\hline $\begin{array}{l}\text { POM/MIL(Cr) } \\
\text { POM/MIL(Al) }\end{array}$ & $\begin{array}{l}\text { T, 1-BT, DBT, 4-MDBT } \\
\text { and 4,6-DMDBT } \\
\text { (500 ppm for each) }\end{array}$ & $\mathrm{H}_{2} \mathrm{O}_{2}$ & 23 & 70 & 120 & $\begin{array}{l}82.0 \\
99.9\end{array}$ & - & [73] \\
\hline $\begin{array}{c}\mathrm{PMo}_{12} @ \mathrm{NH}_{2}-\mathrm{MIL}- \\
101(\mathrm{Cr})\end{array}$ & $\begin{array}{l}\text { BT, DBT, 4-MDBT } \\
\text { and 4,6-DMDBT } \\
\text { (500 ppm for each) }\end{array}$ & $\mathrm{H}_{2} \mathrm{O}_{2}$ & 6 & 50 & 120 & 95 & - & [77] \\
\hline $\begin{array}{c}\text { PTA@MIL- } \\
\text { 101(Cr)@diatomite }\end{array}$ & DBT (500 ppm) & $\mathrm{H}_{2} \mathrm{O}_{2}$ & 5 & 60 & 120 & 98.6 & 0.32 & [78] \\
\hline PMo@HKUST-1(Cu) & $\begin{array}{c}\text { T (250 ppm) } \\
\text { DBT (500 ppm) } \\
\text { BT (1000 ppm) }\end{array}$ & $\mathrm{H}_{2} \mathrm{O}_{2}$ & 6 & 65 & 120 & $\begin{array}{l}90 \\
95 \\
81\end{array}$ & $\begin{array}{c}- \\
12.1\end{array}$ & [82] \\
\hline $\mathrm{PW} / \mathrm{UiO}-66(\mathrm{Zr})$-green & $\begin{array}{c}\text { DBT (1000 ppm) } \\
\text { 4,6-DMDBT (500 ppm) }\end{array}$ & $\mathrm{H}_{2} \mathrm{O}_{2}$ & 6 & 25 & 25 & $\begin{array}{l}99.7 \\
99.8\end{array}$ & $\begin{array}{c}14.9 \\
7.5\end{array}$ & [96] \\
\hline $\begin{array}{c}{\left[\mathrm{mim}\left(\mathrm{CH}_{2}\right)_{3} \mathrm{COO}\right]_{3} \mathrm{PW}} \\
@ \mathrm{UiO}-66(\mathrm{Zr})\end{array}$ & DBT (1000 ppm) & $\mathrm{H}_{2} \mathrm{O}_{2}$ & 5 & 70 & 60 & 100 & 2.7 & [97] \\
\hline
\end{tabular}


Table 4. Cont.

\begin{tabular}{|c|c|c|c|c|c|c|c|c|}
\hline Catalyst & $\begin{array}{l}\text { Substrate } \\
\text { (S Content) }\end{array}$ & Oxidant & $\begin{array}{c}\text { O/S } \\
\text { Ratio }\end{array}$ & $\begin{array}{l}\text { Temp. } \\
\left({ }^{\circ} \mathrm{C}\right)\end{array}$ & $\begin{array}{l}\text { Time } \\
(\mathrm{min})\end{array}$ & $\begin{array}{l}\text { Sulfur } \\
\text { Removal } \\
(\%)\end{array}$ & $\begin{array}{l}\text { Activity } \\
\left(\mathrm{mmol}^{\prime} \mathrm{g}^{-1} \cdot \mathrm{h}^{-1}\right)\end{array}$ & Ref. \\
\hline PTA@MIL-100(Fe) & $\begin{array}{c}\text { BT (950 ppm) } \\
\text { DBT (950 ppm) } \\
\text { 4,6-DMDBT (950 ppm) }\end{array}$ & $\mathrm{H}_{2} \mathrm{O}_{2}$ & 4 & 70 & 60 & $\begin{array}{l}61.8 \\
100 \\
92.8\end{array}$ & & \\
\hline PTA@UiO-66(Zr) & $\begin{array}{c}\text { BT }(950 \mathrm{ppm}) \\
\text { DBT (950 ppm) } \\
\text { 4,6-DMDBT (950 ppm) }\end{array}$ & $\mathrm{H}_{2} \mathrm{O}_{2}$ & 4 & 70 & 60 & $\begin{array}{l}94.8 \\
100 \\
39.1\end{array}$ & - & [92] \\
\hline PTA@ZIF-8(Zn) & $\begin{array}{c}\text { BT (950 ppm) } \\
\text { DBT (950 ppm) } \\
\text { 4,6-DMDBT (950 ppm) }\end{array}$ & $\mathrm{H}_{2} \mathrm{O}_{2}$ & 4 & 70 & 60 & $\begin{array}{c}9.1 \\
28.6 \\
25.7\end{array}$ & & \\
\hline $\mathrm{PW}_{12} @ \mathrm{UiO}-67(\mathrm{Zr})$ & $\begin{array}{l}\text { BT (1000 ppm) } \\
\text { DBT (1000 ppm) } \\
\text { 4,6-DMDBT } \\
(1000 \text { ppm })\end{array}$ & $\mathrm{H}_{2} \mathrm{O}_{2}$ & 13 & 70 & 60 & $\begin{array}{c}75 \\
99.5 \\
80\end{array}$ & - & [98] \\
\hline $\begin{array}{c}\text { 42\%PTA@MOF-808(Zr)- } \\
\text { A }\end{array}$ & DBT (1000 ppm) & $\mathrm{H}_{2} \mathrm{O}_{2}$ & 5 & 60 & 30 & 100 & 7.1 & [99] \\
\hline PTA@TMU-17(Zn)-NH & $\begin{array}{c}\text { BT (169 ppm) } \\
\text { DBT (124 ppm) } \\
\text { 4,6-DMDBT (107 ppm) }\end{array}$ & $\mathrm{H}_{2} \mathrm{O}_{2}$ & 2 & - & 15 & $\begin{array}{l}71 \\
98 \\
87\end{array}$ & $\begin{array}{l}2.6 \\
2.7 \\
2.0\end{array}$ & [79] \\
\hline $\begin{array}{c}\mathrm{PMo}_{6} \mathrm{~W}_{6} \mathrm{O}_{40} @ \mathrm{MOF}- \\
199(\mathrm{Cu}) @ \mathrm{MCM}-41 \\
\mathrm{PMo}_{6} \mathrm{~W}_{6} \mathrm{O}_{40} @ M O F- \\
199(\mathrm{Cu})\end{array}$ & DBT (2000 ppm) & $\mathrm{O}_{2}$ & - & 85 & 180 & $\begin{array}{l}98.5 \\
61.4\end{array}$ & - & [83] \\
\hline $\begin{array}{l}\text { Cs-POM@MOF-199(Cu) } \\
@ M C M-41\end{array}$ & DBT (2000 ppm) & $\mathrm{O}_{2}$ & - & 80 & 180 & 99.6 & $(104.5)^{\mathrm{a}}$ & [84] \\
\hline $\begin{array}{c}\text { C-POM@MOF-199(Cu) } \\
@ M C M-41\end{array}$ & DBT (2000 ppm) & $\mathrm{O}_{2}$ & - & 50 & 90 & 100 & 29.2 & [85] \\
\hline $\begin{array}{c}\text { SRL-POM@MOF- } \\
\text { 199(Cu) } \\
\text { @MCM-41 }\end{array}$ & DBT (2000 ppm) & $\mathrm{O}_{2}$ & & 60 & 150 & 100 & - & [86] \\
\hline POM@MOF-199(Cu) & & & & & & 91.2 & & \\
\hline $\begin{array}{c}@ Z S M-5 \\
\text { POM@MOF-199(Cu) } \\
@ M C M-41\end{array}$ & DBT (2000 ppm) & $\mathrm{O}_{2}$ & - & - & - & 83.5 & - & [88] \\
\hline $\begin{array}{l}\text { POM@MOF- } \\
\text { 199@LZSM-5 }\end{array}$ & DBT (2000 ppm) & $\mathrm{O}_{2}$ & - & 60 & 120 & 100 & $(44.6)^{\mathrm{a}}$ & [89] \\
\hline $\begin{array}{c}\text { 1.5HPA@MOF-199(Cu) } \\
\text { @CA-4 }\end{array}$ & $\mathrm{T}(1000 \mathrm{ppm})$ & $\mathrm{O}_{2}$ & - & 40 & 180 & 99.23 & $(27.6)^{\mathrm{a}}$ & [87] \\
\hline $\begin{array}{c}\text { CNTs@MOF-199(Cu)- } \\
\text { Mo }_{16} V_{2} \\
\mathrm{Fe}_{3} \mathrm{O}_{4} @ M I L-101(\mathrm{Cr})-\end{array}$ & DBT (2000 ppm) & $\mathrm{O}_{2}$ & - & 80 & 180 & 98.3 & $(21.0)^{\mathrm{a}}$ & [90] \\
\hline PMoW & & & & 40 & 60 & 100 & 93.8 & \\
\hline $\begin{array}{c}\mathrm{Fe}_{3} \mathrm{O}_{4} @ \mathrm{MOF}-199(\mathrm{Cu})- \\
\text { PMoW }\end{array}$ & DBT (2000 ppm) & Air & - & 40 & 75 & 97.0 & 72.8 & [19] \\
\hline $\begin{array}{c}\mathrm{Fe}_{3} \mathrm{O}_{4} @ \mathrm{UiO}-66(\mathrm{Zr})- \\
\mathrm{PMoW}\end{array}$ & & & & 60 & 75 & 91.6 & 68.8 & \\
\hline PMA@UiO-66(Zr) & DBT (500 ppm) & TBHP & 3 & 80 & 55 & 100 & 3.4 & [93] \\
\hline $\begin{array}{c}{[\mathrm{Bmim}]_{3} \mathrm{PMo}_{12} \mathrm{O}_{40} / \mathrm{UiO}-} \\
66(\mathrm{Zr}) \\
\mathrm{PMA} / \mathrm{Thiourea} / \mathrm{UiO}- \\
66(\mathrm{Zr})\end{array}$ & DBT (500 ppm) & TBHP & 3 & 80 & 30 & $\begin{array}{l}100 \\
100\end{array}$ & 6.2 & [94] \\
\hline $\mathrm{TiF}_{4}-\mathrm{PU}-200$ & DBT (500 ppm) & ТВНP & 3 & 80 & 30 & $\approx 100$ & - & [95] \\
\hline
\end{tabular}




\subsection{Composites of MOFs with Other Active Species}

It is well known that some metal oxides such as $\mathrm{MoO}_{3}, \mathrm{WO}_{\mathrm{x}}, \mathrm{MnO}_{2}, \mathrm{VO}_{\mathrm{x}}$ can be active phases in the ODS reactions of sulfur compounds. Minoo Bagheri et al. prepared the composite of MOFs and $\mathrm{MoO}_{3}$ by the combination of $\mathrm{Zn}-\mathrm{MOF}$ (TMU-5) and $\mathrm{MoO}_{3}[100,101]$. The obtained material was used for aerobic photooxidation of DBT under UV light, resulting in $95.6 \%$ oxidation rate of DBT (Table 5). However, the leaching of molybdenum ions would occur after reuse. Comparatively, a new magnetic catalyst $\mathrm{Fe}_{3} \mathrm{O}_{4} @ \mathrm{MoO}_{3} @ \mathrm{MOF}-$ $199(\mathrm{Cu})$ obtained by the combination of MOF-199(Cu) with the magnetic core $\mathrm{MoO}_{3} @ \mathrm{Fe}_{3} \mathrm{O}_{4}$ displayed good recycle performance [102]. The catalysts can be collected by magnetic field and recycled 15 times. In the same way, $\mathrm{Fe}_{3} \mathrm{O}_{4} @ \mathrm{~W}-\mathrm{MoO}_{3} @ \mathrm{MOF}-199(\mathrm{Cu})$ with core-shell structure was also prepared by replacing $\mathrm{MoO}_{3}$ with $\mathrm{W}-\mathrm{MoO}_{3}$ [103].

On the basis of UiO-66(Zr), various types of active species including $\mathrm{MnO}_{2}$ [104], $\mathrm{MoO}_{3}$ [105], $\mathrm{WO}_{\mathrm{x}}$ [106] and 1-methylimidazolium-3-propylsulfonate hydrosulfate (abbreviated as $\mathrm{PSMIMHSO}_{4}$ ) [107] were introduced into the pore channels or grafted on the framework of UiO-66(Zr). Therefore, $\mathrm{W} / \mathrm{UiO}-66(\mathrm{Zr})$ prepared by in-situ injection of a single $\mathrm{W}$ site on the node of the defective $\mathrm{UiO}-66(\mathrm{Zr})$ structure by forming a $\mathrm{Zr}-\mathrm{O}-\mathrm{W}$ bond under solvent-free conditions exhibited excellent catalytic performance in the ODS reactions of DBT and 4,6-DMDBT. Such performance was attributed to the presence of single-atom $\mathrm{W}$ sites [106].

1-Sulfopropyl-3-methylimidazolium hydro-sulphate (expressed as ILs) was loaded in the mesoporous structure of MIL-100(Fe), and the DBT (50 ppm) removal rate of $99.31 \%$ was obtained under a high $\mathrm{O} / \mathrm{S}$ ratio of 25 [108]. However, the performance of the material decreased by about $21 \%$ after five reuses. Recently, Qi et al. designed IL@MOF composites by post-synthetic ligand exchange method using carboxyl functionalized ionic liquids as raw materials, and the obtained materials could remove more than 99\% DBT under optimized conditions [109]. The improvement of catalytic performance was attributed to the introduction of ionic liquids to enhance the adsorption capacity of materials, which is more conducive to the contact between reactants and active sites.

Jamali et al. prepared three composite catalyst-supported vanadium species on MIL101(Cr), A520(Al) and MOF-5(Zn), and vanadium(V) oxytributoxide was used as the vanadium source [110]. The catalytic results showed that MIL-101(Cr) and A520(Al) loaded with vanadium species could remove $98 \%$ of DBT (500 ppm) and the ODS reaction might follow a non-radical reaction mechanism (Figure 7). Additionally, the combination of layered double hydroxides (LDHs) with MOF-76(Tb) was made. The resultant composites showed improved ODS activity compared with MOF-76(Tb) [111].

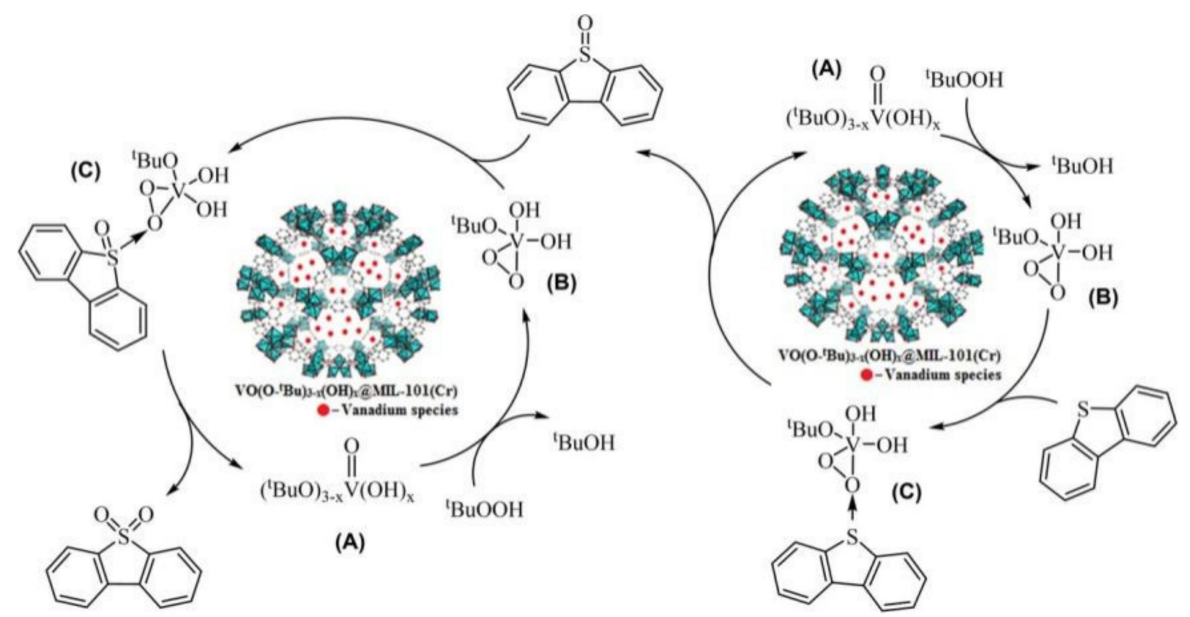

Figure 7. Proposed mechanism for ODS of DBT by OV $\left(\mathrm{O}^{t} \mathrm{Bu}\right)_{3-\mathrm{x}}(\mathrm{OH})_{\mathrm{x}} @ \mathrm{MIL}-101(\mathrm{Cr})$ catalyst in the presence of TBHP (reproduced from Ref. [110], copyright 2020 Wiley). 
Table 5. Comparison of catalytic performance over the composites of MOFs and other active species in the ODS reactions of model fuel oil.

\begin{tabular}{|c|c|c|c|c|c|c|c|c|}
\hline Catalyst & $\begin{array}{l}\text { Substrate } \\
\text { (S Content) }\end{array}$ & Oxidant & $\begin{array}{l}\text { O/S } \\
\text { Ratio }\end{array}$ & $\begin{array}{l}\text { Temp. } \\
\left({ }^{\circ} \mathrm{C}\right)\end{array}$ & $\begin{array}{l}\text { Time } \\
(\min )\end{array}$ & $\begin{array}{l}\text { Sulfur } \\
\text { Removal } \\
(\%)\end{array}$ & 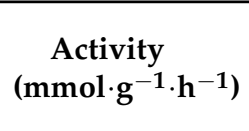 & Ref. \\
\hline $\begin{array}{c}5 \text { wt. } \% \\
\mathrm{MoO}_{3}-\mathrm{TMU}-5(\mathrm{Zn})\end{array}$ & DBT (521 ppm) & Air & - & 20 & 60 & 95.6 & 10.9 & [100] \\
\hline $\begin{array}{c}\mathrm{Fe}_{3} \mathrm{O}_{4} @ \mathrm{MoO}_{3} @ \mathrm{MOF}- \\
199(\mathrm{Cu})\end{array}$ & DBT (2000 ppm) & Air & - & 50 & 45 & 100 & 125.1 & [102] \\
\hline $\begin{array}{c}\mathrm{Fe}_{3} \mathrm{O}_{4} @ \mathrm{~W}-\mathrm{MoO}_{3} @ \mathrm{MOF}- \\
199(\mathrm{Cu})\end{array}$ & DBT (2000 ppm) & Air & - & 40 & 60 & 100 & - & [103] \\
\hline $\mathrm{MnO}_{2} / \mathrm{UiO}-66(\mathrm{Zr})$ & $\begin{array}{c}\text { DBT (347 ppm) } \\
\text { 4,6-DMDBT (347 ppm) }\end{array}$ & $\mathrm{NaClO}$ & 4 & 25 & 5 & $\begin{array}{c}100 \\
94\end{array}$ & - & [104] \\
\hline MoUiO-66(Zr) & DBT (500 ppm) & $\mathrm{H}_{2} \mathrm{O}_{2}$ & 2 & 25 & 50 & 95 & 0.89 & [105] \\
\hline $\mathrm{W} / \mathrm{UiO}-66(\mathrm{Zr})-0.12$ & $\begin{array}{c}\text { DBT (1000 ppm) } \\
\text { BT (500 ppm) } \\
\text { 4,6-DMDBT (500 ppm) }\end{array}$ & $\mathrm{H}_{2} \mathrm{O}_{2}$ & 4 & $\begin{array}{l}30 \\
30 \\
20\end{array}$ & 30 & $\begin{array}{l}99.9 \\
65.3 \\
100\end{array}$ & $\begin{array}{c}14.6 \\
4.8 \\
11.0\end{array}$ & [106] \\
\hline $\begin{array}{c}\mathrm{PSMIMHSO}_{4} @ \mathrm{UiO}- \\
66(\mathrm{Zr})\end{array}$ & BT (2000 ppm) & $\mathrm{H}_{2} \mathrm{O}_{2}$ & 7 & 30 & 20 & 94.6 & 3.0 & [107] \\
\hline 1.1-ILs@MIL-100(Fe) & DBT (50 ppm) & $\mathrm{H}_{2} \mathrm{O}_{2}$ & 25 & 60 & 180 & 99.31 & 0.073 & [108] \\
\hline $\begin{array}{c}{\left[\mathrm{mim}\left(\mathrm{CH}_{2}\right)_{3} \mathrm{COO}\right] \mathrm{FeCl}_{4}} \\
@ \mathrm{UiO}-66(\mathrm{Zr})\end{array}$ & DBT (1000 ppm) & $\mathrm{H}_{2} \mathrm{O}_{2}$ & 5 & 40 & 120 & 99.1 & 1.4 & [109] \\
\hline $\begin{array}{c}\text { MOF-76(Tb)@LDH } \\
\text { OV }\left(\mathrm{O}^{t} \mathrm{Bu}\right)_{3-\mathrm{x}}(\mathrm{OH})_{\mathrm{x}} @ M I L-\end{array}$ & DBT (500 ppm) & $\mathrm{H}_{2} \mathrm{O}_{2}$ & 3 & 60 & 25 & 100 & 13.2 & [111] \\
\hline $\begin{array}{c}101(\mathrm{Cr}) \\
\mathrm{OV}\left(\mathrm{O}^{\mathrm{t}} \mathrm{Bu}\right)_{3-\mathrm{x}}(\mathrm{OH})_{\mathrm{x}} \\
@ \mathrm{~A} 520(\mathrm{Al})\end{array}$ & DBT (500 ppm) & TBHP & 5 & 60 & $\begin{array}{l}60 \\
80\end{array}$ & $\begin{array}{l}98 \\
98\end{array}$ & $\begin{array}{c}10.5 \\
7.9\end{array}$ & [110] \\
\hline
\end{tabular}

\section{MOFs-Derived Materials as ODS Catalysts}

Based on the advantages of high surface area, uniform and rich metal centers, MOFs have been explored as the precursors of active ODS catalysts. For this, MOF-derived materials with mixed nanostructures have been generated by designed synthesis and pyrolysis. The adjustable metal content in MOF-derived materials and the possibility of combining with highly active metal oxides or carbides make them attractive candidates for efficient ODS catalysts. Table 6 shows a detailed comparison of catalytic performance over MOFs-derived materials in the ODS reactions of model fuel oil.

Kim et al. proposed a strategy of high-temperature carbonization and carbon reduction to prepare titanium oxide nanoparticles supported on amorphous carbon with nanoporosity (abbreviated as Ti/NC) by using Ti(O-IPR $)_{4}$-modified IRMOF- $3(\mathrm{Zn})$ as a template and evaluated its catalytic performance in the oxidation reaction of DBT [112]. The catalytic results indicated that Ti/NC had high ODS reactivity $\left(k_{\text {app }}=3.4 \times 10^{-3} \mathrm{~min}^{-1}\right)$ and good cycling stability compared with the materials synthesized by impregnation method. However, the introduced Ti content was low due to the limitation of pore volume by this strategy. In order to overcome the shortage, this research group attempted a pyrolysis strategy using hierarchical micro/meso-MIL-125(Ti) as a template and studied the properties of pyrolysis products at different calcination temperatures [113]. The authors claimed that the titanium content and phase in the final material could be controlled by changing the pyrolysis temperature. The obtained material has higher porosity and catalytic activity for DBT oxidation than that prepared by the pyrolysis of micropore-MIL-125(Ti). In particular, it has been pointed out that more mesopores and smaller titanium nanoparticles in the material are the main reasons for the improvement on catalytic activity. In the same way, a series of V-based carbon catalysts were obtained by pyrolysis of MIL-47(V) at different temperatures [114]. This series of catalysts have the advantages of high V loading (36-68 wt.\%) and high mesoporous ratio $(0.84 \sim 0.91)$. The formation of active vanadium oxides or carbides 
can be controlled by adjusting the pyrolysis temperature. In addition, although MIL-47(V) pyrolysis to form carbon catalysts could enhance their chemical resistance to TBHP, the leaching of active species is still an issue.

Sarker et al., developed a new strategy to synthesize MOFs loaded with Ti precursors inside/outside the pores by regulating the hydrophilic/hydrophobic relationship between the MOFs and Ti precursor. The obtained materials were pyrolyzed at a high temperature to prepare $\mathrm{TiO}_{2}$-integrated carbon materials [115]. The results showed that the oxidation of DBT (1000 ppm) over such catalysts can reach $97.2 \%$ within $1 \mathrm{~h}$ at $80^{\circ} \mathrm{C}$. The authors propose that the particle size of $\mathrm{TiO}_{2}$ is related to the position of Ti precursor. The pyrolysis of MOF loaded with Ti precursor inside the pore can obtain smaller $\mathrm{TiO}_{2}$ particles and higher porosity than those loaded outside the pore, which will lead to superior catalytic activity. In addition, a chromium-titanium oxide hybrid nanocomposite was also reported, which was obtained by the pyrolysis of Ti-modified MIL-101(Cr) [116]. When CHP was used as oxidant, the removal of DBT (1000 ppm) in model oil could reach $90 \%$ within $30 \mathrm{~min}$.

Besides the abovementioned strategies, there are other methods for preparing carbon materials containing metal oxide nanoparticles involving the pyrolysis of MOF@MOF or bimetallic MOF. Bhadra et al. reported porous carbon materials containing $\mathrm{TiO}_{2}$ nanoparticles (MDC-P and MDC-C) synthesized by MIL-125(Ti)-NH ${ }_{2}$ and ZIF-8(Zn)@MIL-125(Ti)$\mathrm{NH}_{2}$ as pyrolysis templates [117]. It can be seen from catalytic data that MDC-C exhibited good ODS activity with 99.5\% removal of DBT (1000 ppm) within $2 \mathrm{~h}$ and can almost maintain initial activity after five cycles. As an example of the pyrolysis from bimetallic MOFs, Bhadra et al. prepared a series of MnO-loaded porous carbon materials (abbreviated as MDNM) by the pyrolysis of $\mathrm{Zn} / \mathrm{Mn}$ bimetallic MOF-74 [118]. It was found that the porosity of MDNM increased with the $\mathrm{Zn}$ content while the size and content of $\mathrm{MnO}$ were reduced, which might be related to the evaporation of $\mathrm{Zn}$ at high temperature. The catalytic results show that the performance of MDNM(75Zn25Mn) is the best among materials with different metal ratios. In addition, bimetallic MAF-6(Zn, Co) was also synthesized and pyrolyzed to obtain Co-loaded N-doped porous carbon [119]. The material MDC$6(75 \mathrm{Zn} 25 \mathrm{Co})-900$ could give a conversion of $93.6 \%$ within $2 \mathrm{~h}$ in ODS of DBT. Further studies suggest that such performance is attributed to high porosity, the synergistic effect of Co-N-carbon, and the uniform dispersion of small size active Co nanoparticles, which is beneficial for improving mass transfer and charge transfer process [120,121].

More recently, the composite of heteropoly acid and MOFs has also been used as pyrolysis template that can produce nitride-loaded porous carbon materials. Mondol et al. first reported the synthesis of $\mathrm{Mo}_{2} \mathrm{~N} @ \mathrm{C}$ by high-temperature pyrolysis of phosphomolybdic acid supported MAF-6(Zn) [122]. When $\mathrm{Mo}_{2} \mathrm{~N} @ \mathrm{C}$ was used as an ODS catalyst, DBT $(1000 \mathrm{ppm})$ in model oil could be completely oxidized within $20 \mathrm{~min}$ at $60^{\circ} \mathrm{C}$. The oxidation of DBT follows a non-radical reaction mechanism. The high catalytic activity is attributed to the contribution of $\mathrm{N}$ in $\mathrm{Mo}_{2} \mathrm{~N}$, which leads to the easy formation of Mo-peroxides. By similar synthesis strategy, $\mathrm{W}_{2} \mathrm{~N} @ \mathrm{C}$ was successfully synthesized and exhibited good catalytic ODS performance (Figure 8) [123].

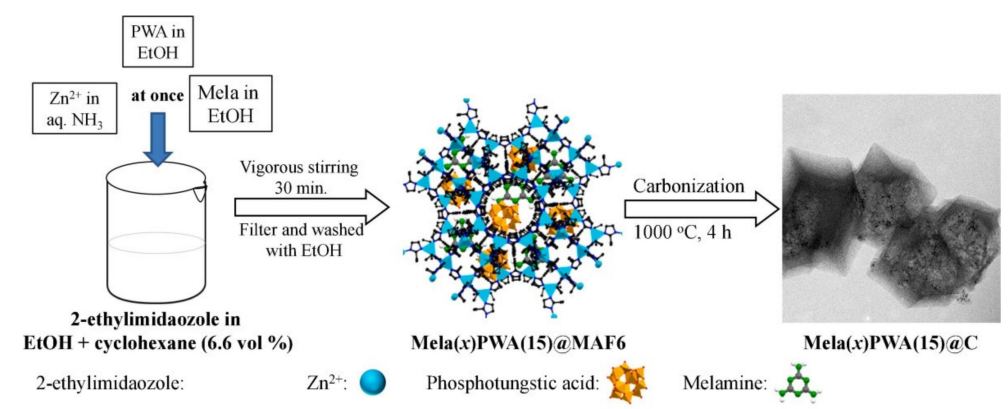

Figure 8. Preparation process of Mela(x)PWA(15)@C material (reproduced from Ref. [123], copyright 2021 Elsevier). 
Table 6. Comparison of catalytic performance over MOFs-derived materials in the ODS reactions of model fuel oil.

\begin{tabular}{|c|c|c|c|c|c|c|c|c|c|}
\hline Catalyst & Precursor MOF & $\begin{array}{l}\text { Substrate } \\
\text { (S Content) }\end{array}$ & Oxidant & $\begin{array}{l}\text { O/S } \\
\text { Ratio }\end{array}$ & $\begin{array}{l}\text { Temp. } \\
\left({ }^{\circ} \mathrm{C}\right)\end{array}$ & $\begin{array}{l}\text { Time } \\
(\mathrm{min})\end{array}$ & $\begin{array}{l}\text { Sulfur } \\
\text { Removal } \\
(\%)\end{array}$ & $\begin{array}{c}\text { Activity } \\
\left(\mathrm{mmol}^{-1} \mathrm{~g}^{-1} \cdot \mathrm{h}^{-1}\right)\end{array}$ & Ref. \\
\hline $\mathrm{Ti} / \mathrm{NC}$ & IRMOF-3(Zn)/Ti & DBT (4896 ppm) & TBHP & 2.14 & 100 & 35 & $\approx 25$ & $(3.4)^{a}$ & [112] \\
\hline meso-1000 & $\begin{array}{l}\text { meso-MIL- } \\
\text { 125(Ti) }\end{array}$ & DBT (500 ppm) & ТВНP & 10 & 80 & 3 & - & - & [113] \\
\hline C1000 & MIL-47(V) & DBT (4870 ppm) & TBHP & 2.15 & 104 & 14 & $\approx 57$ & $(61.9)^{\mathrm{a}}$ & [114] \\
\hline $\begin{array}{l}\text { 50\%Ti-MIL- } \\
101-550\end{array}$ & $\begin{array}{c}\text { 50\%Ti-MIL- } \\
\text { 101(Cr) } \\
\text { TiCl@@MAF- }\end{array}$ & DBT (1000 ppm) & $\mathrm{CHP}$ & - & 60 & 30 & 90 & 11.3 & [116] \\
\hline $\begin{array}{c}\mathrm{TiO}_{2} @ \mathrm{M}-6 \\
\mathrm{TiO}_{2} @ \mathrm{M}-74\end{array}$ & $\begin{array}{c}\mathrm{TiCl}_{4} @ \mathrm{MAF}- \\
6(\mathrm{Zn}) \\
\mathrm{Ti}(\mathrm{SO} 4)_{2} @ \mathrm{MOF}- \\
74(\mathrm{Zn})\end{array}$ & DBT (1000 ppm) & $\mathrm{H}_{2} \mathrm{O}_{2}$ & 15 & 80 & 60 & $\begin{array}{l}97.4 \\
84.1\end{array}$ & $\begin{array}{l}(50)^{\mathrm{a}} \\
(32)^{\mathrm{a}}\end{array}$ & [115] \\
\hline MDC-C & $\begin{array}{c}\text { ZIF-8@MIL- } \\
\text { 125(Ti) } \\
-\mathrm{NH}_{2}\end{array}$ & DBT (1000 ppm) & $\mathrm{H}_{2} \mathrm{O}_{2}$ & 15 & 80 & 120 & 99.5 & 5.5 & [117] \\
\hline $\begin{array}{c}\text { MDNM } \\
\text { (75Zn25Mn) }\end{array}$ & $\begin{array}{c}\text { MOF-74 } \\
\text { (75Zn25Mn) }\end{array}$ & DBT (1000 ppm) & $\mathrm{H}_{2} \mathrm{O}_{2}$ & 20 & 80 & 120 & $\approx 95$ & $(58)^{\mathrm{a}}$ & [118] \\
\hline $\begin{array}{c}\text { MDC-6 } \\
\text { (75Zn25Co)- } \\
900\end{array}$ & $\begin{array}{c}\text { MDC-6 } \\
\text { (75Zn25Co) }\end{array}$ & DBT $(\approx 248$ ppm $)$ & $\mathrm{H}_{2} \mathrm{O}_{2}$ & 15 & 70 & 120 & 93.6 & $(48)^{\mathrm{a}}$ & [119] \\
\hline $\mathrm{Mo}_{2} \mathrm{~N} @ \mathrm{C}-3$ & $\begin{array}{c}\text { PMA(3)@MAF- } \\
\text { 6(Zn) }\end{array}$ & DBT (1000 ppm) & $\mathrm{H}_{2} \mathrm{O}_{2}$ & 10 & 60 & 20 & 100 & $(190)^{a}$ & [122] \\
\hline $\begin{array}{c}\text { Mela(10) } \\
\text { PWA(15)@C }\end{array}$ & $\begin{array}{c}\text { Mela(10) } \\
\text { PWA(15)@ } \\
\text { MAF-6(Zn) }\end{array}$ & DBT (2000 ppm) & $\mathrm{H}_{2} \mathrm{O}_{2}$ & 7.5 & 60 & 15 & 98 & 20.8 & [123] \\
\hline
\end{tabular}

${ }^{\mathrm{a}}$ : kinetic constant $\left[\left(\mathrm{min}^{-1}\right) \times 10^{-3}\right]$, data from literatures.

\section{Summary and Outlook}

In summary, the advances in oxidative desulfurization of fuel oils over MOFs-based heterogeneous catalysts have been reviewed. As shown, many research works have been done in the field. The studied ODS catalysts have mainly involved pure MOFs, composites of MOFs and additional active phases and MOFs-derived materials. The reaction system refers to the use of different oxidants including $\mathrm{H}_{2} \mathrm{O}_{2}, \mathrm{TBHP}, \mathrm{CHP}, \mathrm{O}_{2}$ and air. The reaction temperature is used up to $150^{\circ} \mathrm{C}$, dependent on the reaction system. Generally, the reaction temperature under the conditions of $\mathrm{O}_{2}$ or air as oxidant is higher than that under other oxidants. In some cases, various extractants also had an influence on the catalytic ODS performance. The opportunities and challenges in this field are summarized as follows.

1. As for MOFs as ODS catalysts, most of pure MOFs exhibited poor catalytic ODS performance due to the lack of active sites. However, it has been demonstrated that MOFs with defect sites may improve their performance, especially Zr-based and Ti-based MOFs. Therefore, the design and synthesis of novel Zr-MOFs and Ti-MOFs with abundant defect sites is still challenging.

2. As for composites of MOFs and additional active phases as ODS catalysts, most research works have been focused on the combination of POMs and MOFs. Because the type of POMs is varied, it is undoubted that such combination could supply more chances to develop new catalysts for catalytic ODS of fuel oils, particularly for aerobic ODS.

3. As for MOFs-derived materials as ODS catalysts, more active sites could be created and well dispersed into final materials by this strategy. However, the stability of active sites is still an issue. Meanwhile, high cost resulting from the collapse of MOFs is not beneficial for industrial application. Certainly, such a study is meaningful for the understanding of reaction mechanisms for basic research.

Researchers are still faced with many unsolved problems in the ODS field, although some achievements have been made. Particularly the ODS processes of real fuel oils are very complicated and challenging with air as an oxidant. However, the development of novel MOFs catalysts may provide a good chance to meet the challenges. 
Author Contributions: Writing—original draft preparation, H.L.; visualization, Y.G.; editing, D.L.; supervision, Y.S. All authors have read and agreed to the published version of the manuscript.

Funding: This research received no external funding.

Acknowledgments: Thanks for the financial support from the National Natural Science Foundation of China (No. 22172042), Key Laboratory of Functional Inorganic Material Chemistry (Heilongjiang University), Ministry of Education.

Conflicts of Interest: The authors declare no conflict of interest.

\section{References}

1. Smith, L.V.; Tarui, N.; Yamagata, T. Assessing the impact of COVID-19 on global fossil fuel consumption and $\mathrm{CO}_{2}$ emissions. Energy Econ. 2021, 97, 105170. [CrossRef]

2. Poudyal, R.; Loskot, P.; Nepal, R.; Parajuli, R.; Khadka, S.K. Mitigating the current energy crisis in Nepal with renewable energy sources. Renew. Sustain. Energy Rev. 2019, 116, 109388. [CrossRef]

3. Xu, X.; Nie, S.; Ding, H.; Hou, F.F. Environmental pollution and kidney diseases. Nat. Rev. Nephrol. 2018, 14, 313-324. [CrossRef] [PubMed]

4. Li, K.; Zhao, X.; Xiao, D. Acid rain: An unsuspected factor predisposing Panzhihua airport landslide, China. Environ. Sci. Pollut. Res. Int. 2021, 28, 36753-36764. [CrossRef]

5. Singh, D.; Chopra, A.; Mahendra, P.K.; Kagdiyal, V.; Saxena, D. Sulfur compounds in the fuel range fractions from different crude oils. Pet. Sci. Technol. 2016, 34, 1248-1254. [CrossRef]

6. Liu, Y.; Wang, H.; Zhao, J.; Liu, Y.; Liu, C. Ultra-deep desulfurization by reactive adsorption desulfurization on copper-based catalysts. J. Energy Chem. 2019, 29, 8-16. [CrossRef]

7. Julião, D.; Gomes, A.C.; Pillinger, M.; Valença, R.; Ribeiro, J.C.; Gonçalves, I.S.; Balula, S.S. Desulfurization of liquid fuels by extraction and sulfoxidation using $\mathrm{H}_{2} \mathrm{O}_{2}$ and [CpMo(CO)3R] as catalysts. Appl. Catal. B Environ. 2018, 230, 177-183. [CrossRef]

8. De Rink, R.; Klok, J.B.M.; van Heeringen, G.J.; Sorokin, D.Y.; Ter Heijne, A.; Zeijlmaker, R.; Mos, Y.M.; de Wilde, V.; Keesman, K.J.; Buisman, C.J.N. Increasing the Selectivity for Sulfur Formation in Biological Gas Desulfurization. Environ. Sci. Technol. 2019, 53, 4519-4527. [CrossRef] [PubMed]

9. Shi, Y.; Liu, G.; Zhang, B.; Zhang, X. Oxidation of refractory sulfur compounds with molecular oxygen over a Ce-Mo-O catalyst. Green Chem. 2016, 18, 5273-5279. [CrossRef]

10. Wu, P.; Zhu, W.; Chao, Y.; Zhang, J.; Zhang, P.; Zhu, H.; Li, C.; Chen, Z.; Li, H.; Dai, S. A template-free solvent-mediated synthesis of high surface area boron nitride nanosheets for aerobic oxidative desulfurization. Chem. Commun. 2016, 52, 144-147. [CrossRef]

11. Gu, Q.; Wen, G.; Ding, Y.; Wu, K.-H.; Chen, C.; Su, D. Reduced graphene oxide: A metal-free catalyst for aerobic oxidative desulfurization. Green Chem. 2017, 19, 1175-1181. [CrossRef]

12. Leng, K.; Sun, Y.; Zhang, X.; Yu, M.; Xu, W. Ti-modified hierarchical mordenite as highly active catalyst for oxidative desulfurization of dibenzothiophene. Fuel 2016, 174, 9-16. [CrossRef]

13. Leng, K.; Li, X.; Ye, G.; Du, Y.; Sun, Y.; Xu, W. Ti-containing hierarchical Beta with highly active sites for deep desulfurization of fuels under mild conditions. Catal. Sci. Technol. 2016, 6, 7615-7622. [CrossRef]

14. Piscopo, C.G.; Granadeiro, C.M.; Balula, S.S.; Bošković, D. Metal-Organic Framework-Based Catalysts for Oxidative Desulfurization. ChemCatChem 2020, 12, 4721-4731. [CrossRef]

15. Bhadra, B.N.; Jhung, S.H. Oxidative desulfurization and denitrogenation of fuels using metal-organic framework-based/-derived catalysts. Appl. Catal. B Environ. 2019, 259, 118021. [CrossRef]

16. Kirchon, A.; Feng, L.; Drake, H.F.; Joseph, E.A.; Zhou, H.C. From fundamentals to applications: A toolbox for robust and multifunctional MOF materials. Chem. Soc. Rev. 2018, 47, 8611-8638. [CrossRef] [PubMed]

17. Ye, G.; Qi, H.; Zhou, W.; Xu, W.; Sun, Y. Green and scalable synthesis of nitro- and amino-functionalized UiO-66(Zr) and the effect of functional groups on the oxidative desulfurization performance. Inorg. Chem. Front. 2019, 6, 1267-1274. [CrossRef]

18. Bueken, B.; Van Velthoven, N.; Krajnc, A.; Smolders, S.; Taulelle, F.; Mellot-Draznieks, C.; Mali, G.; Bennett, T.D.; De Vos, D. Tackling the Defect Conundrum in UiO-66: A Mixed-Linker Approach to Engineering Missing Linker Defects. Chem. Mater. 2017, 29, 10478-10486. [CrossRef]

19. Li, S.-W.; Zhang, H.-Y.; Han, T.-H.; Wu, W.-Q.; Wang, W.; Zhao, J.-S. A spinosus $\mathrm{Fe}_{3} \mathrm{O}_{4} @ M O F-P M o W$ catalyst for the highly effective oxidative desulfurization under oxygen as oxidant. Sep. Purif. Technol. 2021, 264, 118460. [CrossRef]

20. Jin, C.; Li, G.; Wang, X.; Zhao, L.; Liu, L.; Liu, H.; Liu, Y.; Zhang, W.; Han, X.; Bao, X. Synthesis, Characterization and Catalytic Performance of Ti-Containing Mesoporous Molecular Sieves Assembled from Titanosilicate Precursors. Chem. Mater. 2007, 19, 1664-1670. [CrossRef]

21. Kim, T.-W.; Kim, M.-J.; Kleitz, F.; Nair, M.M.; Guillet-Nicolas, R.; Jeong, K.-E.; Chae, H.-J.; Kim, C.-U.; Jeong, S.-Y. Tailor-Made Mesoporous Ti-SBA-15 Catalysts for Oxidative Desulfurization of Refractory Aromatic Sulfur Compounds in Transport Fuel. ChemCatChem 2012, 4, 687-697. [CrossRef]

22. Dan-Hardi, M.; Serre, C.; Frot, T.; Rozes, L.; Maurin, G.; Sanchez, C.; Ferey, G. A new photoactive crystalline highly porous titanium(IV) dicarboxylate. J. Am. Chem. Soc. 2009, 131, 10857-10859. [CrossRef] [PubMed] 
23. Kim, S.-N.; Kim, J.; Kim, H.-Y.; Cho, H.-Y.; Ahn, W.-S. Adsorption/catalytic properties of MIL-125 and NH2-MIL-125. Catal. Today 2013, 204, 85-93. [CrossRef]

24. McNamara, N.D.; Hicks, J.C. Chelating agent-free, vapor-assisted crystallization method to synthesize hierarchical microporous/mesoporous MIL-125 (Ti). ACS Appl. Mater. Interfaces 2015, 7, 5338-5346. [CrossRef]

25. Zhang, Y.; Li, G.; Kong, L.; Lu, H. Deep oxidative desulfurization catalyzed by Ti-based metal-organic frameworks. Fuel 2018, 219, 103-110. [CrossRef]

26. Smolders, S.; Willhammar, T.; Krajnc, A.; Sentosun, K.; Wharmby, M.T.; Lomachenko, K.A.; Bals, S.; Mali, G.; Roeffaers, M.B.J.; De Vos, D.E.; et al. A Titanium(IV)-Based Metal-Organic Framework Featuring Defect-Rich Ti-O Sheets as an Oxidative Desulfurization Catalyst. Angew. Chem. Int. Ed. Engl. 2019, 58, 9160-9165. [CrossRef] [PubMed]

27. Ye, G.; Sun, Y.; Zhang, D.; Zhou, W.; Lancelot, C.; Rives, A.; Lamonier, C.; Xu, W. Hierarchical porous titanium terephthalate based material with highly active sites for deep oxidative desulfurization. Microporous Mesoporous Mater. 2018, 270, 241-247. [CrossRef]

28. Ye, G.; Gu, Y.; Zhou, W.; Xu, W.; Sun, Y. Synthesis of Defect-Rich Titanium Terephthalate with the Assistance of Acetic Acid for Room-Temperature Oxidative Desulfurization of Fuel Oil. ACS Catal. 2020, 10, 2384-2394. [CrossRef]

29. Cavka, J.H.; Jakobsen, S.; Olsbye, U.; Guillou, N.; Lamberti, C.; Bordiga, S.; Lillerud, K.P. A new zirconium inorganic building brick forming metal organic frameworks with exceptional stability. J. Am. Chem. Soc. 2008, 130, 13850-13851. [CrossRef]

30. Granadeiro, C.M.; Ribeiro, S.O.; Karmaoui, M.; Valenca, R.; Ribeiro, J.C.; de Castro, B.; Cunha-Silva, L.; Balula, S.S. Production of ultra-deep sulfur-free diesels using a sustainable catalytic system based on UiO-66(Zr). Chem. Commun. 2015, 51, 13818-13821. [CrossRef]

31. Xiao, W.; Dong, Q.; Wang, Y.; Li, Y.; Deng, S.; Zhang, N. Time modulation of defects in UiO-66 and application in oxidative desulfurization. CrystEngComm 2018, 20, 5658-5662. [CrossRef]

32. Zhuang, S.; Cheng, R.; Wang, J. Adsorption of diclofenac from aqueous solution using UiO-66-type metal-organic frameworks. Chem. Eng. J. 2019, 359, 354-362. [CrossRef]

33. Dhakshinamoorthy, A.; Santiago-Portillo, A.; Asiri, A.M.; Garcia, H. Engineering UiO-66 Metal Organic Framework for Heterogeneous Catalysis. ChemCatChem 2019, 11, 899-923. [CrossRef]

34. Ye, G.; Zhang, D.; Li, X.; Leng, K.; Zhang, W.; Ma, J.; Sun, Y.; Xu, W.; Ma, S. Boosting Catalytic Performance of Metal-Organic Framework by Increasing the Defects via a Facile and Green Approach. ACS Appl. Mater. Interfaces 2017, 9, 34937-34943. [CrossRef]

35. Vermoortele, F.; Ameloot, R.; Vimont, A.; Serre, C.; De Vos, D. An amino-modified Zr-terephthalate metal-organic framework as an acid-base catalyst for cross-aldol condensation. Chem. Commun. 2011, 47, 1521-1523. [CrossRef] [PubMed]

36. Zhang, X.; Huang, P.; Liu, A.; Zhu, M. A metal-organic framework for oxidative desulfurization: UIO-66(Zr) as a catalyst. Fuel 2017, 209, 417-423. [CrossRef]

37. Vermoortele, F.; Vandichel, M.; Van de Voorde, B.; Ameloot, R.; Waroquier, M.; Van Speybroeck, V.; De Vos, D.E. Electronic effects of linker substitution on Lewis acid catalysis with metal-organic frameworks. Angew. Chem. Int. Ed. Engl. 2012, 51, 4887-4890. [CrossRef] [PubMed]

38. Peng, Y.; Huang, H.; Zhang, Y.; Kang, C.; Chen, S.; Song, L.; Liu, D.; Zhong, C. A versatile MOF-based trap for heavy metal ion capture and dispersion. Nat. Commun. 2018, 9, 187. [CrossRef]

39. Viana, A.M.; Ribeiro, S.O.; Castro, B.; Balula, S.S.; Cunha-Silva, L. Influence of UiO-66(Zr) Preparation Strategies in Its Catalytic Efficiency for Desulfurization Process. Materials 2019, 12, 3009. [CrossRef]

40. Viana, A.M.; Julião, D.; Mirante, F.; Faria, R.G.; de Castro, B.; Balula, S.S.; Cunha-Silva, L. Straightforward activation of metal-organic framework UiO-66 for oxidative desulfurization processes. Catal. Today 2021, 362, 28-34. [CrossRef]

41. Yang, D.; Gates, B.C. Catalysis by Metal Organic Frameworks: Perspective and Suggestions for Future Research. ACS Catal. 2019, 9, 1779-1798. [CrossRef]

42. Hao, L.; Stoian, S.A.; Weddle, L.R.; Zhang, Q. Zr-Based MOFs for oxidative desulfurization: What matters? Green Chem. 2020, 22, 6351-6356. [CrossRef]

43. Ye, G.; Qi, H.; Li, X.; Leng, K.; Sun, Y.; Xu, W. Enhancement of Oxidative Desulfurization Performance over UiO-66(Zr) by Titanium Ion Exchange. Chemphyschem 2017, 18, 1903-1908. [CrossRef] [PubMed]

44. He, Y.; Wu, Y.; Chen, T.; Weng, W.; Wan, H. Low-temperature catalytic performance for oxidative dehydrogenation of propane on nanosized $\mathrm{Ti}(\mathrm{Zr})-\mathrm{Ni}-\mathrm{O}$ prepared by modified sol-gel method. Catal. Commun. 2006, 7, 268-271. [CrossRef]

45. Ye, G.; Wang, H.; Zeng, X.; Wang, L.; Wang, J. Defect-rich bimetallic UiO-66(Hf-Zr): Solvent-free rapid synthesis and robust ambient-temperature oxidative desulfurization performance. Appl. Catal. B Environ. 2021, 299, 120659. [CrossRef]

46. Fu, G.; Bueken, B.; De Vos, D. Zr-Metal-Organic Framework Catalysts for Oxidative Desulfurization and Their Improvement by Postsynthetic Ligand Exchange. Small Methods 2018, 2, 1800203. [CrossRef]

47. Wang, J.C.; Ding, F.W.; Ma, J.P.; Liu, Q.K.; Cheng, J.Y.; Dong, Y.B. Co(II)-MOF: A Highly Efficient Organic Oxidation Catalyst with Open Metal Sites. Inorg. Chem. 2015, 54, 10865-10872. [CrossRef] [PubMed]

48. Zheng, H.Q.; Zeng, Y.N.; Chen, J.; Lin, R.G.; Zhuang, W.E.; Cao, R.; Lin, Z.J. Zr-Based Metal-Organic Frameworks with Intrinsic Peroxidase-Like Activity for Ultradeep Oxidative Desulfurization: Mechanism of $\mathrm{H}_{2} \mathrm{O}_{2}$ Decomposition. Inorg. Chem. 2019, 58, 6983-6992. [CrossRef] [PubMed] 
49. Ji, P.; Drake, T.; Murakami, A.; Oliveres, P.; Skone, J.H.; Lin, W. Tuning Lewis Acidity of Metal-Organic Frameworks via Perfluorination of Bridging Ligands: Spectroscopic, Theoretical, and Catalytic Studies. J. Am. Chem. Soc. 2018, 140, 10553-10561. [CrossRef]

50. Hao, L.; Hurlock, M.J.; Li, X.; Ding, G.; Kriegsman, K.W.; Guo, X.; Zhang, Q. Efficient oxidative desulfurization using a mesoporous Zr-based MOF. Catal. Today 2020, 350, 64-70. [CrossRef]

51. Mondloch, J.E.; Bury, W.; Fairen-Jimenez, D.; Kwon, S.; DeMarco, E.J.; Weston, M.H.; Sarjeant, A.A.; Nguyen, S.T.; Stair, P.C.; Snurr, R.Q.; et al. Vapor-phase metalation by atomic layer deposition in a metal-organic framework. J. Am. Chem. Soc. 2013, 135, 10294-10297. [CrossRef] [PubMed]

52. Gu, Y.; Ye, G.; Xu, W.; Zhou, W.; Sun, Y. Creation of Active Sites in MOF-808(Zr) by a Facile Route for Oxidative Desulfurization of Model Diesel Oil. ChemistrySelect 2020, 5, 244-251. [CrossRef]

53. McNamara, N.D.; Neumann, G.T.; Masko, E.T.; Urban, J.A.; Hicks, J.C. Catalytic performance and stability of (V) MIL-47 and (Ti) MIL-125 in the oxidative desulfurization of heterocyclic aromatic sulfur compounds. J. Catal. 2013, 305, 217-226. [CrossRef]

54. Wang, D.; Qian, E.W.; Amano, H.; Okata, K.; Ishihara, A.; Kabe, T. Oxidative desulfurization of fuel oil. Appl. Catal. A Gen. 2003, 253, 91-99. [CrossRef]

55. Otsuki, S.; Nonaka, T.; Takashima, N.; Qian, W.; Ishihara, A.; Imai, T.; Kabe, T. Oxidative Desulfurization of Light Gas Oil and Vacuum Gas Oil by Oxidation and Solvent Extraction. Energy Fuels 2000, 14, 1232-1239. [CrossRef]

56. Li, X.; Gu, Y.; Chu, H.; Ye, G.; Zhou, W.; Xu, W.; Sun, Y. MFM-300(V) as an active heterogeneous catalyst for deep desulfurization of fuel oil by aerobic oxidation. Appl. Catal. A Gen. 2019, 584, 117152. [CrossRef]

57. Lu, Z.; Godfrey, H.G.; da Silva, I.; Cheng, Y.; Savage, M.; Tuna, F.; McInnes, E.J.; Teat, S.J.; Gagnon, K.J.; Frogley, M.D.; et al. Modulating supramolecular binding of carbon dioxide in a redox-active porous metal-organic framework. Nat. Commun. 2017, 8, 14212. [CrossRef]

58. Masoomi, M.Y.; Bagheri, M.; Morsali, A. Application of Two Cobalt-Based Metal-Organic Frameworks as Oxidative Desulfurization Catalysts. Inorg. Chem. 2015, 54, 11269-11275. [CrossRef] [PubMed]

59. Abazari, R.; Sanati, S.; Morsali, A.; Slawin, A.; Carpenter-Warren, C.L. Dual-Purpose 3D Pillared Metal-Organic Framework with Excellent Properties for Catalysis of Oxidative Desulfurization and Energy Storage in Asymmetric Supercapacitor. ACS Appl. Mater. Interfaces 2019, 11, 14759-14773. [CrossRef]

60. Gómez-Paricio, A.; Santiago-Portillo, A.; Navalón, S.; Concepción, P.; Alvaro, M.; Garcia, H. MIL-101 promotes the efficient aerobic oxidative desulfurization of dibenzothiophenes. Green Chem. 2016, 18, 508-515. [CrossRef]

61. Vallés-García, C.; Santiago-Portillo, A.; Álvaro, M.; Navalón, S.; García, H. MIL-101(Cr)-NO $\mathrm{NO}_{2}$ as efficient catalyst for the aerobic oxidation of thiophenols and the oxidative desulfurization of dibenzothiophenes. Appl. Catal. A Gen. 2020, 590, 117340. [CrossRef]

62. Zhou, Y.; Guo, Z.; Hou, W.; Wang, Q.; Wang, J. Polyoxometalate-based phase transfer catalysis for liquid-solid organic reactions: A review. Catal. Sci. Technol. 2015, 5, 4324-4335. [CrossRef]

63. Ahmadian, M.; Anbia, M. Oxidative Desulfurization of Liquid Fuels Using Polyoxometalate-Based Catalysts: A Review. Energy Fuels 2021, 35, 10347-10373. [CrossRef]

64. Hu, X.; Lu, Y.; Dai, F.; Liu, C.; Liu, Y. Host-guest synthesis and encapsulation of phosphotungstic acid in MIL-101 via "bottle around ship": An effective catalyst for oxidative desulfurization. Microporous Mesoporous Mater. 2013, 170, 36-44. [CrossRef]

65. Ribeiro, S.; Barbosa, A.D.S.; Gomes, A.C.; Pillinger, M.; Gonçalves, I.S.; Cunha-Silva, L.; Balula, S.S. Catalytic oxidative desulfurization systems based on Keggin phosphotungstate and metal-organic framework MIL-101. Fuel Process. Technol. 2013, 116, 350-357. [CrossRef]

66. Ribeiro, S.; Granadeiro, C.M.; Silva, P.; Almeida Paz, F.A.; de Biani, F.F.; Cunha-Silva, L.; Balula, S.S. An efficient oxidative desulfurization process using terbium-polyoxometalate@MIL-101(Cr). Catal. Sci. Technol. 2013, 3, 2404-2414. [CrossRef]

67. Granadeiro, C.M.; Barbosa, A.D.S.; Ribeiro, S.; Santos, I.C.M.S.; de Castro, B.; Cunha-Silva, L.; Balula, S.S. Oxidative catalytic versatility of a trivacant polyoxotungstate incorporated into MIL-101(Cr). Catal. Sci. Technol. 2014, 4, 1416-1425. [CrossRef]

68. Julião, D.; Gomes, A.C.; Pillinger, M.; Cunha-Silva, L.; de Castro, B.; Gonçalves, I.S.; Balula, S.S. Desulfurization of model diesel by extraction/oxidation using a zinc-substituted polyoxometalate as catalyst under homogeneous and heterogeneous (MIL-101(Cr) encapsulated) conditions. Fuel Process. Technol. 2015, 131, 78-86. [CrossRef]

69. Samaniyan, M.; Mirzaei, M.; Khajavian, R.; Eshtiagh-Hosseini, H.; Streb, C. Heterogeneous Catalysis by Polyoxometalates in Metal-Organic Frameworks. ACS Catal. 2019, 9, 10174-10191. [CrossRef]

70. Lu, Y.; Yue, C.; Liu, B.; Zhang, M.; Li, Y.; Yang, W.; Lin, Y.; Pan, Y.; Sun, D.; Liu, Y. The encapsulation of POM clusters into MIL101(Cr) at molecular level: LaW10O36@MIL-101(Cr), an efficient catalyst for oxidative desulfurization. Microporous Mesoporous Mater. 2021, 311, 110694. [CrossRef]

71. Wang, X.S.; Huang, Y.B.; Lin, Z.J.; Cao, R. Phosphotungstic acid encapsulated in the mesocages of amine-functionalized metal-organic frameworks for catalytic oxidative desulfurization. Dalton Trans. 2014, 43, 11950-11958. [CrossRef]

72. Zhang, L.; Wu, S.; Liu, Y.; Wang, F.; Han, X.; Shang, H. Immobilization of phosphotungstic acid in an amino-containing metal-organic framework for oxidative desulfurization. Appl. Organomet. Chem. 2016, 30, 684-690. [CrossRef]

73. Granadeiro, C.M.; Nogueira, L.S.; Julião, D.; Mirante, F.; Ananias, D.; Balula, S.S.; Cunha-Silva, L. Influence of a porous MOF support on the catalytic performance of Eu-polyoxometalate based materials: Desulfurization of a model diesel. Catal. Sci. Technol. 2016, 6, 1515-1522. [CrossRef] 
74. Hupp, J.T.; Poeppelmeier, K.R. Chemistry. Better living through nanopore chemistry. Science 2005, 309, 2008-2009. [CrossRef] [PubMed]

75. Zhang, F.; Zou, X.; Gao, X.; Fan, S.; Sun, F.; Ren, H.; Zhu, G. Hydrogen Selective NH2-MIL-53(Al) MOF Membranes with High Permeability. Adv. Funct. Mater. 2012, 22, 3583-3590. [CrossRef]

76. Nogueira, L.S.; Ribeiro, S.; Granadeiro, C.M.; Pereira, E.; Feio, G.; Cunha-Silva, L.; Balula, S.S. Novel polyoxometalate silica nano-sized spheres: Efficient catalysts for olefin oxidation and the deep desulfurization process. Dalton Trans. 2014, 43, 9518-9528. [CrossRef]

77. Granadeiro, C.; Ferreira, P.; Julião, D.; Ribeiro, L.; Valença, R.; Ribeiro, J.; Gonçalves, I.; de Castro, B.; Pillinger, M.; Cunha-Silva, L.; et al. Efficient Oxidative Desulfurization Processes Using Polyoxomolybdate Based Catalysts. Energies 2018, 11, 1696. [CrossRef]

78. Sun, M.; Chen, W.-C.; Zhao, L.; Wang, X.-L.; Su, Z.-M. A PTA@MIL-101(Cr)-diatomite composite as catalyst for efficient oxidative desulfurization. Inorg. Chem. Commun. 2018, 87, 30-35. [CrossRef]

79. Afzalinia, A.; Mirzaie, A.; Nikseresht, A.; Musabeygi, T. Ultrasound-assisted oxidative desulfurization process of liquid fuel by phosphotungstic acid encapsulated in a interpenetrating amine-functionalized Zn(II)-based MOF as catalyst. Ultrason. Sonochem 2017, 34, 713-720. [CrossRef]

80. Chui, S.S.; Lo, S.M.; Charmant, J.P.; Orpen, A.G.; Williams, I.D. A chemically functionalizable nanoporous material. Science 1999, 283, 1148-1150. [CrossRef]

81. Song, J.; Luo, Z.; Britt, D.K.; Furukawa, H.; Yaghi, O.M.; Hardcastle, K.I.; Hill, C.L. A multiunit catalyst with synergistic stability and reactivity: A polyoxometalate-metal organic framework for aerobic decontamination. J. Am. Chem. Soc. 2011, 133, 16839-16846. [CrossRef]

82. Rafiee, E.; Nobakht, N. Keggin type heteropoly acid, encapsulated in metal-organic framework: A heterogeneous and recyclable nanocatalyst for selective oxidation of sulfides and deep desulfurization of model fuels. J. Mol. Catal. A Chem. 2015, 398, 17-25. [CrossRef]

83. Li, S.-W.; Gao, R.-M.; Zhang, R.-L.; Zhao, J.-s. Template method for a hybrid catalyst material POM@MOF-199 anchored on MCM-41: Highly oxidative desulfurization of DBT under molecular oxygen. Fuel 2016, 184, 18-27. [CrossRef]

84. Li, S.W.; Li, J.R.; Jin, Q.P.; Yang, Z.; Zhang, R.L.; Gao, R.M.; Zhao, J.S. Preparation of mesoporous Cs-POM@MOF-199@MCM-41 under two different synthetic methods for a highly oxidesulfurization of dibenzothiophene. J. Hazard. Mater. 2017, 337, 208-216. [CrossRef]

85. Li, S.-W.; Gao, R.-M.; Zhao, J.-s. Deep Oxidative Desulfurization of Fuel Catalyzed by Modified Heteropolyacid: The Comparison Performance of Three Kinds of Ionic Liquids. ACS Sustain. Chem. Eng. 2018, 6, 15858-15866. [CrossRef]

86. Li, S.-W.; Yang, Z.; Gao, R.-M.; Zhang, G.; Zhao, J.-s. Direct synthesis of mesoporous SRL-POM@MOF-199@MCM-41 and its highly catalytic performance for the oxidesulfurization of DBT. Appl. Catal. B Environ. 2018, 221, 574-583. [CrossRef]

87. Li, J.; Yang, Z.; Hu, G.; Zhao, J. Heteropolyacid supported MOF fibers for oxidative desulfurization of fuel. Chem. Eng. J. 2020, 388, 124325. [CrossRef]

88. Zhang, Y.; Zhang, W.; Zhang, J.; Dong, Z.; Zhang, X.; Ding, S. One-pot synthesis of cup-like ZSM-5 zeolite and its excellent oxidative desulfurization performance. RSC Adv. 2018, 8, 31979-31983. [CrossRef]

89. Li, S.-W.; Gao, R.-M.; Zhang, W.; Zhang, Y.; Zhao, J.-S. Heteropolyacids supported on macroporous materials POM@MOF199@LZSM-5: Highly catalytic performance in oxidative desulfurization of fuel oil with oxygen. Fuel 2018, 221, 1-11. [CrossRef]

90. Gao, Y.; Lv, Z.; Gao, R.; Zhang, G.; Zheng, Y.; Zhao, J. Oxidative desulfurization process of model fuel under molecular oxygen by polyoxometalate loaded in hybrid material CNTs@MOF-199 as catalyst. J. Hazard. Mater. 2018, 359, 258-265. [CrossRef]

91. Gao, Y.; Liu, Z.; Hu, G.; Gao, R.; Zhao, J. Design and synthesis heteropolyacid modified mesoporous hybrid material CNTs@MOF199 catalyst by different methods for extraction-oxidation desulfurization of model diesel. Microporous Mesoporous Mater. 2020, 291, 109702. [CrossRef]

92. Wang, X.-S.; Li, L.; Liang, J.; Huang, Y.-B.; Cao, R. Boosting Oxidative Desulfurization of Model and Real Gasoline over Phosphotungstic Acid Encapsulated in Metal-Organic Frameworks: The Window Size Matters. ChemCatChem 2017, 9, 971-979. [CrossRef]

93. Zhang, X.-m.; Zhang, Z.; Zhang, B.; Yang, X.; Chang, X.; Zhou, Z.; Wang, D.-H.; Zhang, M.-H.; Bu, X.-H. Synergistic effect of Zr-MOF on phosphomolybdic acid promotes efficient oxidative desulfurization. Appl. Catal. B Environ. 2019, $256,117804$. [CrossRef]

94. Chang, X.; Yang, X.F.; Qiao, Y.; Wang, S.; Zhang, M.H.; Xu, J.; Wang, D.H.; Bu, X.H. Confined Heteropoly Blues in Defected Zr-MOF (Bottle Around Ship) for High-Efficiency Oxidative Desulfurization. Small 2020, 16, e1906432. [CrossRef] [PubMed]

95. Ding, Z.; Zhang, X.M.; Chang, X.; Wang, S.; Wang, D.H.; Zhang, M.H.; Zhang, T.H. Synergistic Effect between Zr-MOF and Phosphomolybdic Acid with the Promotion of TiF4 Template. Molecules 2020, 25, 4673. [CrossRef]

96. Ye, G.; Hu, L.; Gu, Y.; Lancelot, C.; Rives, A.; Lamonier, C.; Nuns, N.; Marinova, M.; Xu, W.; Sun, Y. Synthesis of polyoxometalate encapsulated in $\mathrm{UiO}-66(\mathrm{Zr})$ with hierarchical porosity and double active sites for oxidation desulfurization of fuel oil at room temperature. J. Mater. Chem. A 2020, 8, 19396-19404. [CrossRef]

97. Qi, Z.; Huang, Z.; Wang, H.; Li, L.; Ye, C.; Qiu, T. In situ bridging encapsulation of a carboxyl-functionalized phosphotungstic acid ionic liquid in UiO-66: A remarkable catalyst for oxidative desulfurization. Chem. Eng. Sci. 2020, 225, 115818. [CrossRef] 
98. Peng, Y.-L.; Liu, J.; Zhang, H.-F.; Luo, D.; Li, D. A size-matched POM@MOF composite catalyst for highly efficient and recyclable ultra-deep oxidative fuel desulfurization. Inorg. Chem. Front. 2018, 5, 1563-1569. [CrossRef]

99. Lin, Z.J.; Zheng, H.Q.; Chen, J.; Zhuang, W.E.; Lin, Y.X.; Su, J.W.; Huang, Y.B.; Cao, R. Encapsulation of Phosphotungstic Acid into Metal-Organic Frameworks with Tunable Window Sizes: Screening of PTA@MOF Catalysts for Efficient Oxidative Desulfurization. Inorg. Chem. 2018, 57, 13009-13019. [CrossRef]

100. Bagheri, M.; Masoomi, M.Y.; Morsali, A. A MoO $3-$ Metal-Organic Framework Composite as a Simultaneous Photocatalyst and Catalyst in the PODS Process of Light Oil. ACS Catal. 2017, 7, 6949-6956. [CrossRef]

101. Bagheri, M.; Masoomi, M.Y.; Morsali, A.; Schoedel, A. Two Dimensional Host-Guest Metal-Organic Framework Sensor with High Selectivity and Sensitivity to Picric Acid. ACS Appl. Mater. Interfaces 2016, 8, 21472-21479. [CrossRef]

102. Li, S.-W.; Wang, W.; Zhao, J.-S. Catalytic oxidation of DBT for ultra-deep desulfurization under $\mathrm{MoO}_{3}$ modified magnetic catalyst: The comparison influence on various morphologies of $\mathrm{MoO}_{3}$. Appl. Catal. A Gen. 2020, 602, 117671. [CrossRef]

103. Li, S.-W.; Wang, W.; Zhao, J.-S. Highly effective oxidative desulfurization with magnetic MOF supported $\mathrm{W}_{-} \mathrm{MoO}_{3}$ catalyst under oxygen as oxidant. Appl. Catal. B Environ. 2020, 277, 119224. [CrossRef]

104. Subhan, S.; Yaseen, M.; Ahmad, B.; Tong, Z. Fabrication of $\mathrm{MnO}_{2} \mathrm{NPs}$ incorporated UiO-66 for the green and efficient oxidative desulfurization and denitrogenation of fuel oils. J. Environ. Chem. Eng. 2021, 9, 105179. [CrossRef]

105. Afzali, N.; Kardanpour, R.; Zadehahmadi, F.; Tangestaninejad, S.; Moghadam, M.; Mirkhani, V.; Mechler, A.; Mohammadpoor-Baltork, I.; Bahadori, M. Molybdenum (VI)-functionalized UiO-66 provides an efficient heterogeneous nanocatalyst in oxidation reactions. Appl. Organomet. Chem. 2019, 33, e5225. [CrossRef]

106. Ye, G.; Wang, H.; Chen, W.; Chu, H.; Wei, J.; Wang, D.; Wang, J.; Li, Y. In Situ Implanting of Single Tungsten Sites into Defective UiO-66(Zr) by Solvent-Free Route for Efficient Oxidative Desulfurization at Room Temperature. Angew. Chem. Int. Ed. Engl. 2021, 60, 20318-20324. [CrossRef]

107. Wu, J.; Gao, Y.; Zhang, W.; Tan, Y.; Tang, A.; Men, Y.; Tang, B. Deep desulfurization by oxidation using an active ionic liquidsupported Zr metal-organic framework as catalyst. Appl. Organomet. Chem. 2015, 29, 96-100. [CrossRef]

108. Yang, W.; Guo, G.; Mei, Z.; Yu, Y. Deep oxidative desulfurization of model fuels catalysed by immobilized ionic liquid on MIL-100(Fe). RSC Adv. 2019, 9, 21804-21809. [CrossRef]

109. Qi, Z.; Qiu, T.; Wang, H.; Ye, C. Synthesis of ionic-liquid-functionalized UiO-66 framework by post-synthetic ligand exchange for the ultra-deep desulfurization. Fuel 2020, 268, 117336. [CrossRef]

110. Jamali, M.A.; Arvani, A.; Amini, M.M. Vanadium Containing Metal-organic Frameworks as Highly Efficient Catalysts for the Oxidation of Refractory Aromatic Sulfur Compounds. ChemCatChem 2020, 13, 293-303. [CrossRef]

111. Liu, S.; Li, X.; Zhang, H. Synergistic effects of MOF-76 on layered double hydroxides with superior activity for extractive catalytic oxidative desulfurization. New J. Chem. 2020, 44, 6269-6276. [CrossRef]

112. Kim, J.; McNamara, N.D.; Her, T.H.; Hicks, J.C. Carbothermal reduction of Ti-modified IRMOF-3: An adaptable synthetic method to support catalytic nanoparticles on carbon. ACS Appl. Mater. Interfaces 2013, 5, 11479-11487. [CrossRef] [PubMed]

113. McNamara, N.D.; Kim, J.; Hicks, J.C. Controlling the Pyrolysis Conditions of Microporous/Mesoporous MIL-125 To Synthesize Porous, Carbon-Supported Ti Catalysts with Targeted Ti Phases for the Oxidation of Dibenzothiophene. Energy Fuels 2015, 30, 594-602. [CrossRef]

114. Kim, J.; McNamara, N.D.; Hicks, J.C. Catalytic activity and stability of carbon supported V oxides and carbides synthesized via pyrolysis of MIL-47 (V). Appl. Catal. A Gen. 2016, 517, 141-150. [CrossRef]

115. Sarker, M.; Bhadra, B.N.; Shin, S.; Jhung, S.H. TiO 2 -Integrated Carbon Prepared via Pyrolysis of Ti-Loaded Metal-Organic Frameworks for Redox Catalysis. ACS Appl. Nano Mater. 2018, 2, 191-201. [CrossRef]

116. Li, X.; Zhang, L.; Sun, Y. Titanium-Modified MIL-101(Cr) Derived Titanium-Chromium-Oxide as Highly Efficient Oxidative Desulfurization Catalyst. Catalysts 2020, 10, 1091. [CrossRef]

117. Bhadra, B.N.; Song, J.Y.; Khan, N.A.; Jhung, S.H. $\mathrm{TiO}_{2}$-Containing Carbon Derived from a Metal-Organic Framework Composite: A Highly Active Catalyst for Oxidative Desulfurization. ACS Appl. Mater. Interfaces 2017, 9, 31192-31202. [CrossRef] [PubMed]

118. Bhadra, B.N.; Jhung, S.H. Well-dispersed Ni or MnO nanoparticles on mesoporous carbons: Preparation via carbonization of bimetallic MOF-74s for highly reactive redox catalysts. Nanoscale 2018, 10, 15035-15047. [CrossRef]

119. Bhadra, B.N.; Khan, N.A.; Jhung, S.H. Co supported on N-doped carbon, derived from bimetallic azolate framework-6: A highly effective oxidative desulfurization catalyst. J. Mater. Chem. A 2019, 7, 17823-17833. [CrossRef]

120. Chen, H.; Shen, K.; Mao, Q.; Chen, J.; Li, Y. Nanoreactor of MOF-Derived Yolk-Shell Co@C-N: Precisely Controllable Structure and Enhanced Catalytic Activity. ACS Catal. 2018, 8, 1417-1426. [CrossRef]

121. He, L.; Weniger, F.; Neumann, H.; Beller, M. Synthesis, Characterization, and Application of Metal Nanoparticles Supported on Nitrogen-Doped Carbon: Catalysis beyond Electrochemistry. Angew. Chem. Int. Ed. Engl. 2016, 55, 12582-12594. [CrossRef] [PubMed]

122. Mondol, M.M.H.; Bhadra, B.N.; Jhung, S.H. Molybdenum nitride@porous carbon, derived from phosphomolybdic acid loaded metal-azolate framework-6: A highly effective catalyst for oxidative desulfurization. Appl. Catal. B Environ. 2021, $288,119988$. [CrossRef]

123. Bhadra, B.N.; Jhung, S.H. Oxidative desulfurization of liquid fuel with tungsten-nitride@porous carbon, derived from MAF-6(Zn) loaded with phosphotungstic acid and melamine. Chem. Eng. J. 2021, 419, 129485. [CrossRef] 